Article

\title{
An Influence of the Fuel Type on Element Behaviour in Domestic Boilers with Respect to the Circular Economy
}

\author{
Helena Raclavská ${ }^{1}{ }^{\oplus}$, Pavel Kantor ${ }^{1}$, Jana Růžičková ${ }^{1}$, Marek Kucbel ${ }^{1, *} \mathbb{C}$, Barbora Švédová ${ }^{1}(\mathbb{D}$, \\ Karolina Slamová ${ }^{2}$, Šárka Flodrová ${ }^{3}$ and Dagmar Juchelková ${ }^{4}$ (D)
}

1 Centre ENET-Energy Units for Utilisation of Non-Traditional Energy Sources, VŠB-Technical University of Ostrava, 17. listopadu 15/2172, 70800 Ostrava-Poruba, Czech Republic; helena.raclavska@vsb.cz (H.R.); pavel.kantor@vsb.cz (P.K.); jana.ruzickova@vsb.cz (J.R.); barbora.svedova@vsb.cz (B.Š.)

2 Institute of Foreign Languages, VŠB-Technical University of Ostrava, 17. listopadu 15/2172, 70800 Ostrava-Poruba, Czech Republic; karolina.slamova@vsb.cz

3 Department of Power Engineering, VŠB-Technical University of Ostrava, 17. listopadu 15/2172, 70800 Ostrava-Poruba, Czech Republic; sarka.flodrova@vsb.cz

4 Department of Electronics, Faculty of Electrical Engineering and Computer Science, VŠB-Technical University of Ostrava, 17. listopadu 15/2172, 70800 Ostrava-Poruba, Czech Republic; dagmar.juchelkova@vsb.cz

* Correspondence: marek.kucbel@vsb.cz; Tel.: +420-597-325-448

check for

updates

Citation: Raclavská, H.; Kantor, P.; Růžičková, J.; Kucbel, M.; Švédová, B.; Slamová, K.; Flodrová, Š.; Juchelková, D. An Influence of the Fuel Type on Element Behaviour in Domestic Boilers with Respect to the Circular Economy. Appl. Sci. 2021, 11, 4980. https://doi.org/10.3390/ app11114980

Academic Editor: Adrian Irimescu

Received: 27 April 2021

Accepted: 26 May 2021

Published: 28 May 2021

Publisher's Note: MDPI stays neutral with regard to jurisdictional claims in published maps and institutional affiliations.

Copyright: (c) 2021 by the authors. Licensee MDPI, Basel, Switzerland. This article is an open access article distributed under the terms and conditions of the Creative Commons Attribution (CC BY) license (https:// creativecommons.org/licenses/by/ $4.0 /)$.

\begin{abstract}
The use of waste from the regional production of waste wood, waste paper, and cardboard in the form of briquettes may be causing an increase in local emissions, both of major elements and trace elements. When burning paper and cardboard briquettes, more than $70 \%$ of $\mathrm{Mn}, \mathrm{Zn}$, As, and $\mathrm{Pb}$ is released into the air from the total content of trace elements in the fuel. The largest amounts of major and trace elements are released when burning paper briquettes ( $56 \mathrm{~g} / \mathrm{kg}$ of fuel); half of these amounts are released from burning briquettes from waste wood and coal ( $23 \mathrm{~g} / \mathrm{kg}$ of fuel). The pursuit of alternative uses for those cardboard components that are not suitable for recycling cannot be directed to the production of briquettes for residential combustion in the framework of the application of the principles of the circular economy. In particular, the high concentrations of undesirable elements in the emissions released in the gas phase into the atmosphere are an obstacle existing even when the parameters of the $\mathrm{PM}_{10}$ emissions of a boiler are met. This is related to the high ash content of the cardboard (13.5\%). Waste paper or cardboard could be added to waste wood at a maximum of $10 \%$ to make the pollution produced comparable to the burning of coal briquettes.
\end{abstract}

Keywords: waste paper; cardboard; waste wood; coal; ash; residential wood combustion

\section{Introduction}

The use of biomass as renewable, carbon-neutral fuel for heat and electric energy is strongly supported in the EU. This support has triggered a sharp increase in the use of wood, which increases every year [1]. The rapid development of residential wood combustion (RWC) is linked to the positive image of wood as domestic and renewable fuel [2]. Increasing pressure to limit the European biomass market requires compliance with the conditions for its sustainable utilisation. This suggests that the future cost of biomass will change depending on many factors: local conditions, resource availability, and sustainability criteria [3]. A non-questionable role will be played by improving the use of waste biomass within the circular economy. The wood industry and many governments promote the utilisation of wood, while many environmental groups oppose wood bioenergy because it causes deforestation, which harms natural carbon sinks, ecosystems, and biodiversity [4]. The pros and cons of using wood waste as a source of heat and energy within the circular economy are explained by Millward-Hopkins and Purnel [5].

Residential wood combustion (RWC) is an important contributor to air quality in numerous regions worldwide. In central and eastern Europe, the contribution from RWC 
is estimated at $32 \%$ of the total $\mathrm{PM}_{2.5}$ concentration [6], up to $45 \%$ of $R W C^{\prime} \mathrm{S} \mathrm{PM}_{2.5}$ [7]. Annual average fractions of $\mathrm{PM}_{2.5}$ concentrations attributed to RWC form up to $70 \%$ (Oslo), equivalent to $7.8 \mathrm{mg} / \mathrm{m}^{3}$ [6]. The contribution of wood smoke to ambient PM was highly dependent on seasonality, the density of sources, specific technologies used, meteorology, and topography [8]. The most important pollutants include CO, particulate matter (PM), elemental carbon (EC), organic carbon (OC), polyaromatic hydrocarbons [9] and heavy metals- $\mathrm{Pb}, \mathrm{Cu}, \mathrm{Fe}, \mathrm{Zn}, \mathrm{Hg}$, and others [6]. Emitted $\mathrm{OC}$ is converted by atmospheric oxidation to a secondary organic aerosol [8].

Even a relatively "clean fuel" can produce significant pollution, which is mainly affected by an inappropriate fuel burning rate and poorly mixed ratios between fuel and air. Older boilers are known to produce higher dust emission loads than modern boiler types. The pollution produced by traditional logwood boilers is $5-10$ times (different for each pollutant) higher than in the case of modern logwood boilers and pellet boilers [10]. Emission factors, which are key indicators in terms of emission control strategies, are used to estimate the emission burden from domestic boilers.

The literature references state that particle emission factors from residential biomass combustion may show wide variation due to the type of biomass burned, the characteristics of combustion facility, and burning rate [11,12]. In addition to the technical parameters of the boiler and the combustion conditions, the emission of dust particles is significantly influenced by the fuel type (wood logs, chips, pellet, briquettes) and also for new kinds of biofuel made from residues from other activities, such as forestry or the furniture industry [13]. The use of waste wood and other biomass products is particularly encouraged by the circular economy.

In an overloaded boiler of older production, emissions from burning wood biomass increase 2-6 times, while moist fuel increases emissions 1.5 to 2 times. In modern boilers, $\mathrm{PM}_{2.5}$ emissions are increased 8-10 times using higher humidity fuel due to the limited capacity of the air systems [10]. By burning too-dry fuel at a high load, modern boilers increase their $\mathrm{PM}_{2.5}$ emissions 4-5 times compared to a nominal load and standard fuel.

At the present time, emission factors (EF) for fine inhalable particles, with diameters that are generally 2.5 micrometres and smaller than $\mathrm{PM}_{2.5}$, are being monitored. Older published data reported the emission factor for dust particles (without size limitation). The difference between the emission factors for dust particles and $\mathrm{PM}_{2.5}$ particles was observed by Shen et al. [9]. The emission factor values for PM from logwood combustion are in the range of $0.71-6.2 \mathrm{~g} / \mathrm{kg}$ with an average value of $2.1 \pm 1.3 \mathrm{~g} / \mathrm{kg}$, and for $\mathrm{PM}_{2.5}$ particles, they are in the almost identical range of $0.5-6.0 \mathrm{~g} / \mathrm{kg}$ with an average value of $1.8 \pm 1.3 \mathrm{~g} / \mathrm{kg}$.

Measurements from Norway, where the highest wood stove emissions factor for birch and spruce was found to be $36 \mathrm{~g} / \mathrm{kg}$ [14], demonstrate a high variability of emission factors when burning wood biomass. Under standard conditions and at a steady state (nominal load), the emissions from the combustion of $\mathrm{PM}_{2.5}$ reach up to $84 \mathrm{mg} / \mathrm{MJ}(1.34 \mathrm{~g} / \mathrm{kg}$ of fuel for $16 \mathrm{MJ} / \mathrm{kg}$ in gross calorific value). This value increased to $105 \mathrm{mg} / \mathrm{MJ}$ when the ignition phase is included in the measurement. During burning wet log fuelwood, the value increases by $27 \%$ to $568 \mathrm{mg} / \mathrm{MJ}$ [10].

Differing values of emission factors have been published. For example, according to the EMEP/EEA Guidebook [15], the emission factor ranges are as follows: for modern boilers (advanced or eco-labelled) the $\mathrm{PM}_{2.5}$ average value is $93 \mathrm{mg} / \mathrm{MJ}$ ranging from 19 to $33 \mathrm{mg} / \mathrm{MJ}$, for traditional boilers 470 (235-940) mg/MJ, pellet boilers 29 (9-47) mg/MJ, and for older boilers 740 (370-1480) $\mathrm{mg} / \mathrm{MJ}$, equivalent to approximately $23.6 \mathrm{~g} / \mathrm{kg}$ of fuel with a gross calorific value of $16 \mathrm{MJ} / \mathrm{kg}$ [15]. For old boilers, Klimont et al. [16] report an even higher emission factor value for dust particles (73-2200 mg/MJ). The PM emission factor is significantly higher in briquette combustion than with fuelwood, the value of which is $7.76 \pm 6.02 \mathrm{~g} / \mathrm{kg}$ [17].

The PM emission factor for the combustion of bituminous coal briquettes ranges from $0.17-26 \mathrm{~g} / \mathrm{kg}$ to $0.13 \mathrm{~g} / \mathrm{kg}$ for $\mathrm{PM}_{2.5}$. When burning bituminous coal briquettes, 
more significant differences were found for the average emission factor value for PM $(3.5 \pm 6.5 \mathrm{~g} / \mathrm{kg})$ and for $\mathrm{PM}_{2.5} 7.7 \pm 5.8 \mathrm{~g} / \mathrm{kg}$ [9]. A substantially higher emission factor for bituminous coal $(14.4 \mathrm{~g} / \mathrm{kg})$ is reported by Butcher and Ellenbecker [11]. The EF value for anthracite coal was reported to be only $0.5 \mathrm{~g} / \mathrm{kg}$, which is related to a low volatile flammable substance content and a high fixed carbon content, which stabilised combustion during the heating period [18].

The $\mathrm{EF} \mathrm{PM}_{2.5}$ values for old boilers indicate that the amounts of particles produced may be higher during burning biomass than when burning bituminous coal $[9,16]$. Emission factors represent a significant step for an objective comparison of the technical parameters of the combustion equipment for standardised fuels. When burning biomass, some elements go into a gaseous phase depending on the combustion temperature; therefore, they are not included in the EF. The resulting environmental load of burning biomass will be higher.

During wood combustion, $85-100 \%$ of $\mathrm{Cl}$ and approximately $50-70 \%$ of $\mathrm{S}$ are already released at $500{ }^{\circ} \mathrm{C}$ into the gaseous phase [19]. The release of $\mathrm{Na}, \mathrm{K}, \mathrm{Zn}$, and $\mathrm{Pb}$ is influenced by the type of biomass and temperature. $\mathrm{Zn}$ and $\mathrm{Pb}$ start to be released at $500{ }^{\circ} \mathrm{C}$, and at $850{ }^{\circ} \mathrm{C}$, more than $65-85 \%$ of the total element content is released into the air [20]. When burning biomass, amounts of trace elements are released in the following order: $\mathrm{As}>\mathrm{Cd}$, $\mathrm{Pb}, \mathrm{Zn}>\mathrm{Cu}$ [20]. Of the major elements, $70-90 \%$ of $\mathrm{K}$ and $\mathrm{Na}$ are released at a higher temperature $\left(800-1050{ }^{\circ} \mathrm{C}\right)$ [19]. At $1000{ }^{\circ} \mathrm{C}$, 94 to $99 \%$ of $\mathrm{K}$ and $97-99 \%$ of $\mathrm{Na}$ are released depending on the original concentration of the element in biomass [21]. The release of $\mathrm{Si}$ and $\mathrm{Ca}$ into the gas phase in smaller quantities than $\mathrm{K}$ and $\mathrm{S}$ is reported by Trojanowski and Fthenakis [7]. Burning biomass, especially waste biomass (mixture of waste from furniture production and wood waste) or waste cardboard, can cause a higher environmental load than burning fossil fuels.

The article aims to compare the amounts of released major and trace elements during the combustion of fuels prepared from waste biomass and fossil fuels and highlight the dangers associated with the presence of harmful substances released into the atmosphere. These problems are particularly significant in using waste wood as a small part of biomass fuel because protective chemical compounds (pesticides, fire retardants) or dyes, inks, and additives used to modify the properties of paper are important sources of trace elements. The importance of this research is linked to the "pressure" to secure cheaper fuels and meet the objectives of the circular economy-using waste as a potential raw material. Studying the behaviour of major and trace elements was also aimed at monitoring the possibility of using deposits in the flue duct to identify the burned fuel.

\section{Material and Methods}

\subsection{Material}

Three types of fuels were used (fossil fuel and two types of biomass) of approximately "same shape"-briquettes (Table 1).

Table 1. Proximate and ultimate analysis of combusted fuels in dry matter.

\begin{tabular}{ccccccccccc}
\hline \multirow{2}{*}{ Fuel } & Moisture & VM & FC & Ash & C & H & N & S & O & GCV \\
\cline { 2 - 10 } & & & & \% & & & & & MJ/kg \\
\hline CB & $\max 19$ & 50.61 & 42.89 & 5.50 & 58.97 & 4.92 & 0.67 & $<0.50$ & 29.94 & 19.2 \\
REKORD 7 & $\max 8$ & 75.23 & 23.82 & 0.95 & 46.27 & 5.42 & 1.64 & 0.71 & 44.10 & 17.8 \\
WM & $\max 8$ & 79.65 & 7.15 & 13.2 & 38.30 & 5.29 & 0.11 & $<0.10$ & 43.30 & 16.1 \\
PB & & & & & & & &
\end{tabular}


Coal briquettes (CB) with the trade name "REKORD 7" come from lignite in the Lumber Range (Welzow-Süd and Nochten mines) which are further processed by Lausitz Energie Bergbau AG (LEAG) at the Schwarze Pumpe plant. The briquettes are produced without binders and are available at all fuel suppliers in the Czech Republic. The sales price plus VAT is EUR $2.67 / 10 \mathrm{~kg}$. The advantage of CB briquettes for domestic heating is a higher fixed-carbon content.

Paper briquettes ((PB) SaverBrik POWER type RUF-P (manufacturer SaverBrik, the Czech Republic)) are produced from mixture of coarsely crushed cardboard and recovered paper using high pressure. The sales price of these briquettes ranges from 0.85 to $1.25 \mathrm{EUR} / 10 \mathrm{~kg}$ with VAT.

Briquettes made from waste wood from furniture production (WM) with the addition of wood-processing waste containing polymer materials-veneer, wood, wood composites, and MDF (medium-density fibrewood) products come from a plant (Ostravice, Moravian-Silesian Region, the Czech Republic) corresponding to category 1.2.3 "homogeneous mixtures and mixtures" defined by ISO 17225-7 (WM) [22]. The sales price plus VAT is EUR 2.24/10 kg. Therefore, the costs of obtaining $100 \mathrm{MJ}$ are comparable for briquettes CB and WM (EUR 1.3 and EUR 1.2), while for PB, it is half the cost (EUR 0.6).

In addition to the input fuel, combustion products were analysed: ash (A)-samples taken from the bottom of the boiler and deposits (D) - samples taken from the wall of the boiler and heat exchange surface (Table 2). Char/soot terminology is used for high-carbon material in atmospheric deposition. Char retains the morphology of the source material with diameters ranging mainly from 1 to $100 \mu \mathrm{m}$ [23]. Soot is submicron particles $(<1 \mu \mathrm{m})$ formed from the condensation of hydrocarbon radicals at high temperature $\left(>600{ }^{\circ} \mathrm{C}\right)$ via conversions in flue gas [24]. As the samples taken did not fit either definition (particle size, presence of a primary particle structure from the fuel), they were marked as deposits.

Table 2. Conditions for combustion experiments in EC2, EC3 boilers.

\begin{tabular}{|c|c|c|c|c|c|c|c|c|c|c|c|c|c|c|}
\hline \multicolumn{5}{|c|}{ Paper Briquettes (PB) } & \multicolumn{5}{|c|}{ Wood Mixture (WM) } & \multicolumn{5}{|c|}{ Coal Briquettes (CB) } \\
\hline \multirow{2}{*}{ Sample } & D & A & FC & TC & \multirow{2}{*}{ Sample } & $\mathbf{D}$ & $\mathbf{A}$ & FC & TC & \multirow{2}{*}{ Sample } & $\mathbf{D}$ & A & \multirow{2}{*}{$\begin{array}{c}\text { FC } \\
\mathrm{kg} / \mathrm{h}\end{array}$} & \multirow{2}{*}{$\begin{array}{c}\text { TC } \\
\mathbf{h}\end{array}$} \\
\hline & \multicolumn{2}{|c|}{ g/kg Fuel } & $\mathrm{kg} / \mathrm{h}$ & $\mathbf{h}$ & & \multicolumn{2}{|c|}{ g/kg Fuel } & $\mathrm{kg} / \mathrm{h}$ & $\mathbf{h}$ & & \multicolumn{2}{|c|}{ g/kg Fuel } & & \\
\hline $\begin{array}{l}\text { EC2 } \\
134\end{array}$ & 0.55 & 110 & 3.40 & 9.0 & \multirow{7}{*}{$\begin{array}{l}\text { EC2 } \\
128 \\
\text { EC2 } \\
129 \\
\text { EC2 } \\
130\end{array}$} & 0.81 & 9.37 & 2.93 & 4 & EC2 51 & 0.40 & 65.1 & 2.86 & 10.5 \\
\hline $\begin{array}{l}\text { EC2 } \\
135\end{array}$ & 0.59 & 107 & 4.70 & 7.5 & & 0.92 & 9.58 & 2.25 & 3 & EC2 55 & 0.47 & 67.3 & 2.86 & 10.5 \\
\hline $\begin{array}{l}\text { EC2 } \\
146\end{array}$ & 0.51 & 157 & 6.00 & 8.5 & & 1.18 & 10.94 & 2.25 & 4 & EC2 58 & 0.41 & 43.0 & 3.71 & 10.5 \\
\hline $\begin{array}{l}\text { EC2 } \\
147\end{array}$ & 0.61 & 134 & 5.20 & 8.5 & & & & & & EC2 65 & 0.43 & 52.1 & 3.76 & 10.0 \\
\hline & & & & & & & & & & EC2 66 & 0.45 & 55.1 & 3.54 & 10.0 \\
\hline $\begin{array}{l}\text { EC2 } \\
\text { AVG }\end{array}$ & 0.57 & 127 & 4.83 & 8.38 & & 0.97 & 9.96 & 2.48 & 3.67 & & 0.43 & 56.5 & 3.35 & 10.30 \\
\hline $\begin{array}{l}\text { EC2 } \\
\text { STD }\end{array}$ & 0.04 & 23.4 & 1.09 & 0.63 & & 0.16 & 0.85 & 0.32 & 0.47 & & 0.03 & 8.90 & 0.41 & 0.24 \\
\hline $\begin{array}{l}\text { EC3 } \\
168\end{array}$ & 1.10 & 128 & 3.80 & 10.5 & \multirow{7}{*}{$\begin{array}{c}\text { EC3 } \\
125 \\
\text { EC3 } \\
126 \\
\text { EC3 } \\
127\end{array}$} & 0.15 & 7.72 & 3.89 & 4 & EC3 64 & 0.47 & 67.3 & 2.40 & 12.5 \\
\hline $\begin{array}{l}\text { EC3 } \\
170\end{array}$ & 0.92 & 131 & 3.80 & 10.5 & & 0.16 & 7.59 & 4.44 & 4 & EC3 72 & 0.60 & 43.5 & 3.81 & 10.5 \\
\hline $\begin{array}{l}\text { EC3 } \\
180\end{array}$ & 0.75 & 125 & 4.00 & 10.0 & & 0.25 & 8.26 & 3.75 & 4 & EC3 73 & 0.49 & 42.9 & 3.75 & 12.0 \\
\hline $\begin{array}{l}\text { EC3 } \\
181\end{array}$ & 1.00 & 115 & 4.20 & 9.50 & & & & & & EC3 76 & 0.53 & 62.7 & 2.73 & 11.0 \\
\hline $\begin{array}{l}\text { EC3 } \\
183\end{array}$ & 0.94 & 149 & 3.00 & 10.0 & & & & & & & & & & \\
\hline $\begin{array}{l}\text { EC3 } \\
\text { AVG }\end{array}$ & 0.94 & 129 & 3.77 & 10.10 & & 0.19 & 7.86 & 4.03 & 4.00 & & 0.52 & 54.1 & 3.17 & 11.5 \\
\hline $\begin{array}{l}\text { EC3 } \\
\text { STD }\end{array}$ & 0.13 & 12.5 & 0.46 & 0.42 & & 0.06 & 0.36 & 0.36 & 0.00 & & 0.06 & 12.7 & 0.72 & 0.91 \\
\hline
\end{tabular}

Explanation: A—Ash; AVG—Arithmetic mean; D—Deposits; FC—Fuel consumption; STD—Standard deviation; TC—Time of combustion.

\subsection{Conditions of the Combustion}

WM briquettes were burnt in continuous burning boilers of emission class EC2 (BEC2) and EC3 (BEC3) defined according to EN 303-5 [25]. Boilers had manual stoking.

Boilers differ in design elements: in particular, the arrangement of heat-exchanging surfaces, the intensity of the burning, or the ways of feeding primary and secondary air, the arrangement of the burn-out chamber, and the turbulence inside the combustion chamber. 
The advantages of EC3 boilers, for example, are turbofans installed to allow more intense thermal decomposition and the more precise positioning of the air vents on the grate. Currently, the approximate frequencies of representation of both groups in local heating are equal.

The combustion tests were conducted at a minimum of six hours with approximately the same thermal operation. Constant marginal conditions were ensured, including, for example, heat collection, fuel grain size composition, amount and method of fuel supply, and ambient temperature. The walls of the EC3 boiler are lined with a chamotte lining to help maintain a higher temperature in the boiler. Information on the amount of burned fuel, sediment production, and ash are given in Table 2.

Six combustion tests were carried out with WM briquettes, three for each boiler. PB briquettes were burned ten times (five times in the EC2 boiler and five times in the EC3 boiler. One test for the EC2 boiler was excluded due to poor fuel burn, which was caused by a lack of air supply.

\subsection{Analytical Methods}

Samples of the deposits WM, PB, CB and ash from WM and PB were screened on sieves: $0.045,0.125,0.25,0.50,1.00,2.00$, and $2.50 \mathrm{~mm}$ (Preciselekt, Czech Republic) at the sieving machine Fritsch Analysette 3 Spartan. Ash from the combustion of CB was very coarse; therefore, 6.3 - and $12.5-\mathrm{mm}$ sieves were added. The weight proportions of particles for individual grain size classes were determined as a base for the calculation of the yield.

The mineralogical phase analyses of the deposits and samples were performed by X-ray diffraction (Diffractometer Bruker Advance D8) using the standard Rietveld method of quantitative phase analysis. Analysis of organic compounds in WM fuel was done by the Py-GC/MS method. Sample preparation and measurement methods are described in detail by Ruzickova et al. [26]. The other methods used are standardised, and their overview, including information on the instrumentation used, is given in Table 3.

Table 3. Overview of standardised methods used.

\begin{tabular}{llll}
\hline Matrix & Parameter & Standard/Methods & Equipment \\
\hline A, D, F & Ash & ISO 18122:2015 [27] & $\begin{array}{l}\text { Laboratory furnace LAC LH, } \\
\text { Czech Republic }\end{array}$ \\
A, D, F & Ultimate analysis (C,H,N) & ISO 16948:2015 [28] & FleshSmart Elemental Analyser. \\
A, D, F & S-determination & ISO 16994:2016 [27] & Thermoscientific \\
F & Calorific value & ISO 18125:2017 [29] & Calorimeter AC 500, LECO, USA \\
A, D, F & Elemental analysis-X-ray & U.S. EPA 2007, method 6200 [30] & Innov-X analyser, Olympus \\
F & fluorescence & ISO 18134-2:2017 [31] & Memmert UN30, Germany \\
A, D & Moisture & EN 12457-2 [32] & Overhead shaker GFL 3040, \\
& Water leachate & & Germany \\
WL & Major anions (chloride) & U.S. EPA 1997, Method 300.1 [33] & $\begin{array}{l}\text { Ion chromatograph 940 } \\
\text { Professional IC Vario }\end{array}$ \\
F(coal), A & Grain size analysis & ASTM D293/D293M-18 [34] & Vibratory sieve shaker Analysette \\
F(bio), A & Grain size analysis & ISO 17827-2:2016 [35] & 3 Spartan, Fritsch, Germany \\
\hline
\end{tabular}

Explanation: A-Ash; Bio-biomass; D-Deposit; F-Fuel, WL-Water leachate.

\section{Results}

\subsection{Basic Information about the Burning Process}

The amounts of ash obtained by burning $1 \mathrm{~kg}$ of fuel in BEC2 and BEC3 are approximately equivalent to the laboratory results of the determination of ash in fuel according to ISO 18122:2015 [27] (Table 1). Burning $1 \mathrm{~kg}$ of CB under laboratory conditions would yield $55 \mathrm{~g} / \mathrm{kg}$ of ash, while burning in BEC2 yielded $56.5 \pm 8.9 \mathrm{~g} / \mathrm{kg}$ and BEC3 $54.1 \pm 11.0 \mathrm{~g} / \mathrm{kg}$ (Figure 1). Additionally, the amounts of deposits produced were comparable for both boilers. These were $0.43 \pm 0.03 \mathrm{~g} / \mathrm{kg}$ for the EC2 boiler and $0.52 \pm 0.05 \mathrm{~g} / \mathrm{kg}$ 
for the EC3 boiler (Figure 2). While burning PB under laboratory conditions produced $127 \pm 23 \mathrm{~g} / \mathrm{kg}$ of ash in BEC2, and $118 \pm 45 \mathrm{~g} / \mathrm{kg}$ of ash in the EC3 boiler, the amounts of deposits captured differed for the BEC2 and BEC 3 boiler. The higher amounts of deposits were collected in the BEC3 boiler $(0.94 \pm 0.13 \mathrm{~g} / \mathrm{kg})$, while in BEC2, it was $0.57 \pm 0.04 \mathrm{~g} / \mathrm{kg}$ of fuel. The difference is caused by the higher uptake of inorganic particles in the BEC3 deposits $(22.7 \pm 3.84 \%)$ than in BEC2 $(19.5 \pm 1.73 \%)$, which confirmed the higher efficiency of the EC3 boiler in capturing inorganic particles resulting from the condensation of the gaseous component. The biggest difference is shown in the results obtained by burning WM when substantially smaller amounts of ash were produced. In BEC3, the amount of ash obtained (7.86 $\pm 0.29 \mathrm{~g} / \mathrm{kg}$ of fuel) was lower than the ash determined according to ISO 18122:2015 [27] (9.5 g/ $\mathrm{kg}$ of fuel).
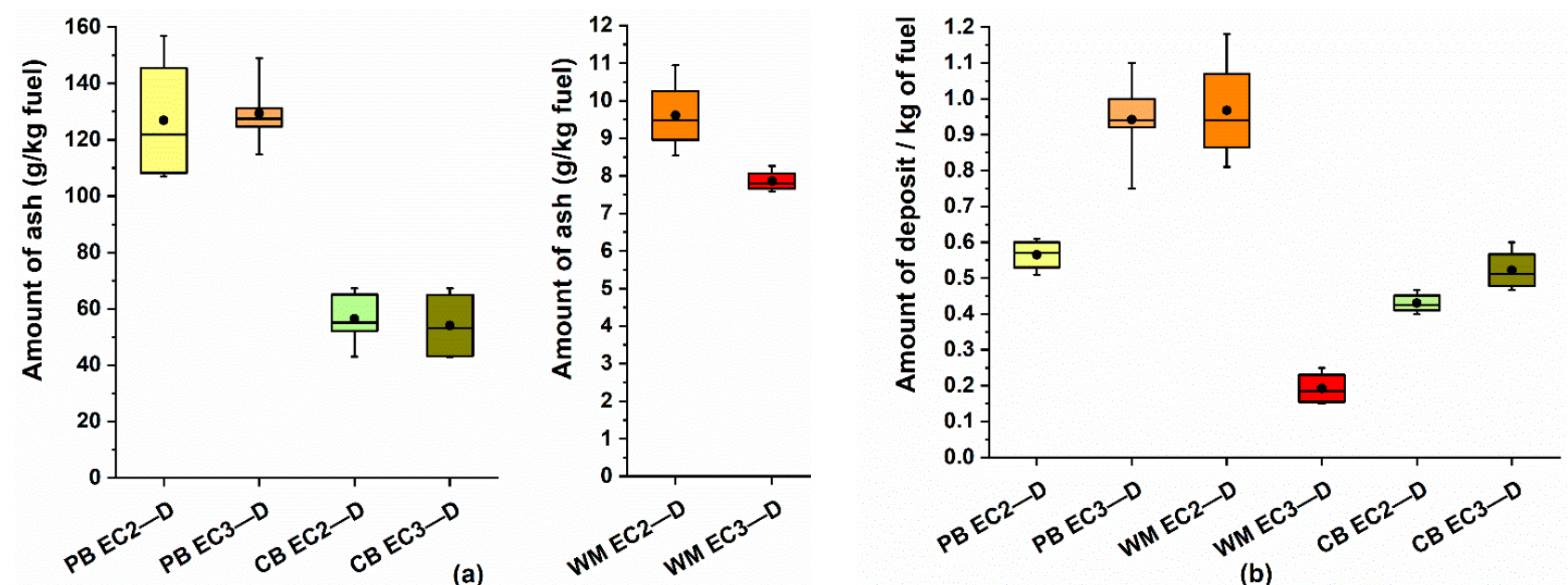

(b)

Figure 1. Amounts of ash (a) and deposits (b) formed by the combustion of $1 \mathrm{~kg}$ of fuel.

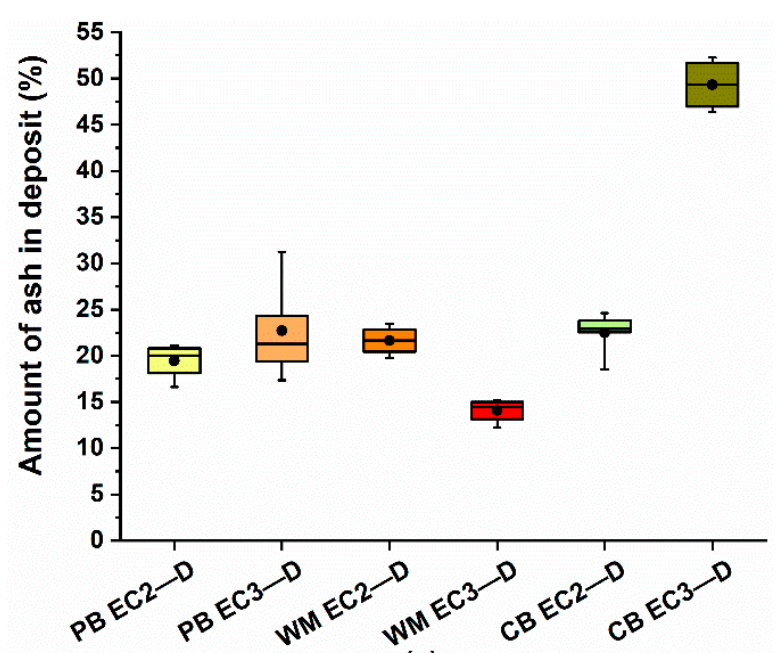

(a)

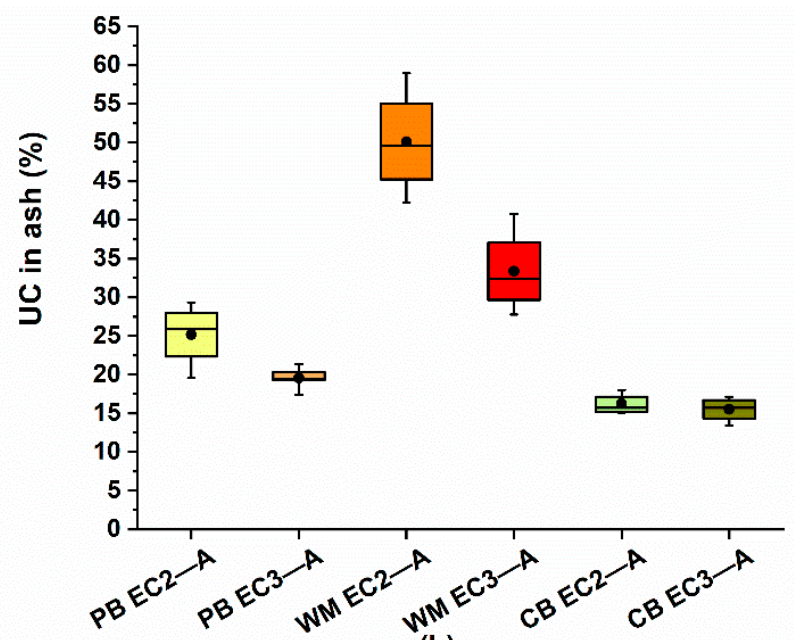

(b)

Figure 2. Amounts of inorganic component (ash) in deposits (a) and amounts of unburned carbon in deposits (b).

In this case, when the content of inorganic elements in the input fuel is minimal, the amounts of deposits captured in BEC3 is lower $(0.19 \pm 0.04 \mathrm{~g} / \mathrm{kg}$ of fuel $)$ than in BEC2 $(0.97 \pm 0.16 \mathrm{~g} / \mathrm{kg}$ of fuel $)$. As a result, only $13.82 \pm 1.21 \%$ of the inorganic component was captured in the deposits from BEC3, compared to $21.81 \pm 1.05 \%$ in BEC2. When burning in BEC2, the temperature was probably lower, which did not allow further thermal decomposition of the major mineral phase of $\mathrm{Ca}$ (calcite). The X-ray diffraction method determined the calcite content in deposits from BEC2 $10.56 \pm 2.02 \%$ and in deposits from BEC3 $3.58 \pm 0.64 \%$ (normalised to 100\%). In the deposits from the EC3 boiler, 
$1.69 \%$ of $\mathrm{Ca}$ is in the form of calcite, which corresponds to $31 \%$ of the total Ca bound in the crystalline phase. In the deposits from the EC2 boiler, $4.75 \%$ of Ca is bound in the crystalline phase, which is equivalent to $54.5 \%$ of the total Ca content in the deposit. The higher temperature in the EC3 boiler was confirmed by the predominant amorphous character of the deposit particles.

\subsection{The Form of Occurrence of Elements in Fuels}

\subsubsection{Waste Paper and Cardboard}

The high fibre plant material content and low ash content of the waste paper are interesting in terms of its further energy use. Corrugated cardboard contains up to $95 \%$ of organic matter, while printing paper contains $70-100 \%$ of organic matter and $0-30 \%$ of inorganic matter. The chemical composition of the paper depends on the type or grade of the paper. Paper is a heterogeneous mixture of fibre plant material-mostly cellulose, hemicellulose and, in smaller quantities, lignin or various compounds of lignin (Na-lignate) and inorganic compounds (filler). The fibre in newsprint is composed of $45.6 \%$ cellulose, $31.3 \%$ hemicellulose, and $23.1 \%$ lignin [36]. In paper production, to improve surface characteristics of paper, the following chemical compounds are used as precipitators and stabilizers: aluminium sulphate, aluminium chloride hydroxide, aluminium formiate, aluminium nitrate, and sodium aluminium components [37].

A significant component of the paper is coating pigments (4\%) and chemical additives (3-8\%), whose use depends on the grade of the paper [38]. Printing is also the source of trace elements in waste paper. The main components of the inks are colouring substances (5-30\%), binders (15-50\%), solvents (15-65\%), and additives (1-10\%). Lead compounds $\mathrm{PbCrO}_{4}, \mathrm{PbSO}_{4}$, and $\mathrm{PbO}$ are used to produce yellow and green dyes and pigments [39]. Lead is also part of white ink. The main component of cyan in the colour printing processes is copper (II) phthalocyanine blue $\left(\mathrm{C}_{32} \mathrm{H}_{16} \mathrm{CuN}_{8}\right)$. Nickel occurs as part of multiple colourants [40].

The content of major elements and selected trace elements in CB is shown in Table 4. The source of the major inorganic elements in the waste paper is the filler used. By concentration, major elements form the series $\mathrm{Ca}>\mathrm{Si}>\mathrm{Al}>\mathrm{Fe}=\mathrm{K}=\mathrm{S}>\mathrm{Ti}$, while the order of trace elements is $\mathrm{Mn}>>\mathrm{Zn}>\mathrm{Cu}>\mathrm{Pb}>\mathrm{Ni}=\mathrm{Cr}$.

Table 4. Chemical composition of inorganic elements in waste paper and paper briquettes.

\begin{tabular}{|c|c|c|c|c|c|c|c|c|c|c|c|c|c|c|c|c|}
\hline \multirow{2}{*}{ Waste Paper } & Al & $\mathrm{Si}$ & $\mathrm{Ca}$ & $\mathrm{Fe}$ & $\mathrm{Ti}$ & $\mathbf{P}$ & $\mathrm{S}$ & K & $\mathrm{Cl}$ & Mn & $\mathrm{Cr}$ & $\mathrm{Ni}$ & $\mathrm{Cu}$ & $\mathrm{Zn}$ & $\mathbf{P b}$ & As \\
\hline & \multicolumn{8}{|c|}{$\%$} & \multicolumn{8}{|c|}{$\mathrm{mg} / \mathrm{kg}$} \\
\hline $\begin{array}{l}\mathrm{PB} \\
\text { WOP * }\end{array}$ & $\begin{array}{c}0.67 \\
0.036\end{array}$ & 1.76 & $\begin{array}{l}7.85 \\
8.50\end{array}$ & $\begin{array}{l}0.23 \\
0.37\end{array}$ & 0.11 & 0.12 & 0.21 & 0.22 & 263.6 & $\begin{array}{l}520 \\
260\end{array}$ & 7 & 9 & $\begin{array}{l}54 \\
14\end{array}$ & 95 & 25 & 3 \\
\hline Card board ** & $0.034-1.14$ & & & & & & & & & & $0.5-6.2$ & $0.9-4.9$ & $0.2-167$ & $1.4-61.3$ & $1.4-12.8$ & \\
\hline Paper *** & $0.03-1.14$ & & & & & & & & & & $0.5-2.7$ & $\begin{array}{l}1.03- \\
3.3\end{array}$ & $0.5-17.3$ & $3.0-10.1$ & $1.4-12.8$ & \\
\hline Paperboard $* * *$ & $0.14-0.56$ & & & & & & & & & & $0.9-2.7$ & $0.9-2.5$ & $0.9-49.7$ & $1.4-7.4$ & $1.5-11.1$ & \\
\hline $\begin{array}{l}\text { Corrugated } \\
\text { board } * * *\end{array}$ & $0.12-0.40$ & & & & & & & & & & $1.3-6.2$ & $2.5-4.9$ & $0.2-166.6$ & $14.0-61.3$ & $1.4-12.8$ & \\
\hline
\end{tabular}

Explanations: * Wang et al. [41]; ${ }^{* *}$ Mertoglu-Elmas [42]; ${ }^{* * *}$ Elmas and Çınar [37]; WOP-Waste office paper.

The high Ca content is related to the use of calcium carbonate or calcium sulfate as a filler (0-25\%) in the production of paper [41]. Silicates may also be used as a filler-clay, talk and oxides (titanium oxide). Mn is a biogenic element derived from wood biomass that occurs in wood and wood biomass at a concentration of $430 \mathrm{mg} / \mathrm{kg}$ [43]. As a filler and for enhancement of coating, $\mathrm{Zn}$ is used in the form of $\mathrm{ZnO}, \mathrm{ZnS}$, and lithophone (a blend of $\mathrm{BaSO}_{4}$ with $\mathrm{ZnS}$ ) in the production of cardboard products [42], which explains the highest levels of $\mathrm{Zn}$ in PB compared to WM and CB. Manganese is present in biomass as an essential element [44].

During repeated recycling of waste paper, there is a further increase in the concentration of Mn, but also of other elements $\mathrm{Zn}, \mathrm{Ni}, \mathrm{Cu}$ (Otto et al., 2021), which probably explains the higher levels than Elmas and Çınar [37] reported for the cardboard used in the food industry, where the content of selected trace elements is capped by the "Packaging Waste Directive 2018/852/EU” [45]. 


\subsubsection{Waste Wood from the Furniture Production}

The inorganic components contained in biomass and in biomass ash can be divided by their concentration into major $(>1 \%)$, minor $(1-0.1 \%)$, and trace $(<0.1 \%)$ elements [46]. The bonding type of elements affects their release during the combustion process. Ash-forming elements ( $\mathrm{Al}, \mathrm{Ca}, \mathrm{Cl}, \mathrm{Fe}, \mathrm{K}, \mathrm{Mg}, \mathrm{P}, \mathrm{Na}, \mathrm{S}, \mathrm{Mn}, \mathrm{Si}$, and $\mathrm{Ti}$ ) in biomass may be bound in an inorganic or organic component. The method of inorganic binding elements in biomass is described by Vassilev et al. [47]. Inorganic elements $\mathrm{Al}, \mathrm{Ca}, \mathrm{Cl}, \mathrm{Fe}, \mathrm{K}, \mathrm{Mg}, \mathrm{Mn}, \mathrm{Na}, \mathrm{P}, \mathrm{S}$, and $\mathrm{Si}$ associated with organic matter are bound directly in organic groups, complexes, matrix, and structures. Elements $\mathrm{Ca}, \mathrm{K}, \mathrm{Mg}, \mathrm{Mn}$, and $\mathrm{Na}$ are bound in carbohydrates, $\mathrm{Fe}$ in chelates, $\mathrm{Cu}, \mathrm{Mg}, \mathrm{Mn}, \mathrm{Mo}, \mathrm{N}$, and Ti in chlorophyll, $\mathrm{Ni}$ in citrates, $\mathrm{P}$ and $\mathrm{Si}$ in esters. Phosphorus is bound by phospholipids, phytates [48] and in proteins where $\mathrm{Mg}, \mathrm{Mn}, \mathrm{N}, \mathrm{P}$, and $\mathrm{S}$ can also be bound. $\mathrm{Ca}$ and $\mathrm{Mg}$ are bound in pectates and oxalates together with $\mathrm{K}$, $\mathrm{Mn}$, and $\mathrm{Na}$. Fe, $\mathrm{N}$, and $\mathrm{S}$ may occur in binding to organic $\mathrm{S}$ (amino acids, sulfate esters, sulfolipids, sulfonates, and proteins. Organo-metallic compounds are formed with $\mathrm{Hg}$ and K [47].

In inorganic form, the biomass contains $\mathrm{Ca}, \mathrm{Mg}, \mathrm{K}, \mathrm{Na}, \mathrm{Fe}$, and $\mathrm{Mn}$, which are bound in carbonates, phosphates, and silicates, where $\mathrm{Al}$ and Ti also enter. Important inorganic phases are oxyhydroxides, which contain $\mathrm{Ca}, \mathrm{Mg}, \mathrm{Fe}, \mathrm{Mn}, \mathrm{Al}$, and Ti. Elements $\mathrm{Ca}, \mathrm{Mg}, \mathrm{K}$ and $\mathrm{Na}$. $\mathrm{Ca}, \mathrm{Na}, \mathrm{K}$, and $\mathrm{Al}$ may be present in the form of sulfates. Moreover, in the original biomass, all inorganic elements also occur in a water-soluble form [43].

The most significant source of trace elements contained in virgin wood is the application of preservatives. Pesticides used for forest protection may contain $\mathrm{Hg}, \mathrm{Cu}, \mathrm{Pb}, \mathrm{Zn}$, $\mathrm{Cd}, \mathrm{Ni}, \mathrm{Mn}$, and $\mathrm{As}$ in the form of calcium arsenate or sodium arsenate [40]. Chemical compounds used for surface treatment (siccatives) contain $\mathrm{Zn}, \mathrm{Cd}, \mathrm{Pb}, \mathrm{Cu}$, and $\mathrm{Cr}$ [49]. The most common wood-preservatives include chromated copper arsenate (CCA), $\mathrm{Cu}$ preservative without $\mathrm{Cr}$ (ammoniacal copper quaternary-ACQ, copper azole, copper citrate, and copper ethanolamine), boron and $\mathrm{Al}$ compounds [50,51]. Preservative-treated wood contains $1-2 \%$ of heavy metals [51]. Content of inorganic elements in WM, wood and wood treated with preservative collected from literature data are listed in Table 5.

Table 5. Content of inorganic elements in WM, wood and wood treated with preservative (literature data).

\begin{tabular}{|c|c|c|c|c|c|c|c|c|c|c|c|c|c|c|c|c|}
\hline $\begin{array}{l}\text { Wood } \\
\text { Mixture }\end{array}$ & Al & $\mathrm{Si}$ & $\mathrm{Ca}$ & $\mathrm{Fe}$ & $\mathrm{Ti}$ & $\mathbf{P}$ & $S$ & $\mathbf{K}$ & $\mathrm{Cl}$ & Mn & $\mathrm{Cr}$ & $\mathrm{Ni}$ & $\mathrm{Cu}$ & $\mathrm{Zn}$ & $\mathrm{Pb}$ & As \\
\hline & \multicolumn{8}{|c|}{$(\%)$} & \multicolumn{8}{|c|}{$\mathrm{mg} / \mathrm{kg}$} \\
\hline WM & 0.32 & 0.81 & 1.51 & 0.22 & 0.02 & 0.77 & 0.03 & 0.21 & 68.4 & 300 & 4 & 7 & 20 & 200 & 8 & 2.4 \\
\hline Wood * & 0.003 & 0.093 & 0.75 & 0.0005 & & BDL & 0.015 & 0.02 & 114 & 100 & & & & & & \\
\hline Bark * & 0.009 & 0.02 & 0.83 & 0.0039 & & 0.045 & 0.036 & 0.21 & 260 & 714 & & & & & & \\
\hline STW ** & & & & & & & & & & & 60 & 3.5 & 59 & 440 & & 53 \\
\hline${ }_{* * *}^{\text {STW }}$ CCA & & & & & & & & & & & $4300-9100$ & & $2800-5500$ & & & $3100-7600$ \\
\hline
\end{tabular}

Explanation: * Werkelin et al. [52]; ${ }^{* *}$ Krook et al. [49]; ${ }^{* * *}$ Kim et al. [51]; CCA—Chromated copper arsenate; STW—surface-treated wood.

The contents of major elements in WM decreases in the following order: $\mathrm{Ca}>\mathrm{Si}>\mathrm{P}$ $>\mathrm{Al}>\mathrm{Fe}=\mathrm{K}>\mathrm{S}>\mathrm{Ti}$; and for trace elements $\mathrm{Mn}>\mathrm{Zn}>>\mathrm{Cu}>\mathrm{Pb}=\mathrm{Ni}>\mathrm{Cr}$. $\mathrm{Zn}$ is an essential element in plants [44]. In untreated stem wood (spruce) is a concentration of $\mathrm{Zn}<$ $100 \mathrm{mg} / \mathrm{kg}$ d.m. [53]. WM fuel contains a Zn concentration of $200 \mathrm{mg} / \mathrm{kg}$, indicating the presence of $\mathrm{Zn}$ of anthropogenic origin (siccatives). The anthropogenic contamination of $\mathrm{WM}$ is also evidenced by the increased $\mathrm{Al}$ concentration, which is about ten times higher than the average $\mathrm{Al}$ concentration in plants $-0.02 \mathrm{wt} . \%$ and the $\mathrm{Fe} / \mathrm{Mn}$ ratio, which is $>1[54]$.

\subsubsection{Elements in Coal}

Elements in coal occur in different forms and concentrations depending on genetic conditions, most of the major elements being discrete minerals [55]. The presence of trace elements is linked to the degree of coalification [56]. Trace elements in coal may be present in many different forms; for example, they may occur in silicates, sulfides, carbonates, oxides, sulfates, phosphates, selenides, and halides, or they may be bound to the surfaces 
of minerals or the organic matter. Gluskoter [57] already identified elements primarily bound to the inorganic component ( $\mathrm{As}, \mathrm{Cd}, \mathrm{Co}, \mathrm{Cr}, \mathrm{Cu}, \mathrm{Hg}, \mathrm{Mn}, \mathrm{Mo}, \mathrm{Ni}, \mathrm{Pb}$, and $\mathrm{Zn}$ ) and elements bound to the organic component ( $\mathrm{B}, \mathrm{Be}, \mathrm{Ga}, \mathrm{Ge}, \mathrm{P}, \mathrm{Sb}, \mathrm{Se}$, and $\mathrm{V})$. According to their organic or inorganic affinity, the different division of elements was developed by Lewińska-Preis et al. [58]. They distinguish the occurrence in mineral phases for $\mathrm{Zn}, \mathrm{Cd}$, $\mathrm{Mn}$, and $\mathrm{Pb}$, while the link to the organic component of coal (organometallic complexes, chelates or ion-exchange compounds) is typical for $\mathrm{Co}, \mathrm{Cr}$, and $\mathrm{Cu}$. Organic compounds bound in lignite from the total content: $60 \%$ of $\mathrm{Mg}$ and $\mathrm{Na}, 50 \%$ of $\mathrm{V}, 35 \%$ of $\mathrm{Al}, \mathrm{Ca}$ and $\mathrm{Co}$, $30 \%$ of $\mathrm{As}$ and $\mathrm{Ni}, 25 \%$ of $\mathrm{K}, 20 \%$ of $\mathrm{Cu}, 15 \%$ of $\mathrm{P}$, Ti and $\mathrm{Zn}, 10 \%$ of $\mathrm{Cr}$ and $\mathrm{Mn}$, and $5 \%$ of Fe [56].

It is clear from Table 6 that the contents of the major elements correspond to the published concentrations. Only the measured concentration of $\mathrm{Ca}$ is significantly below the value reported under the certificate of Free Company and slightly below the value reported by Vassilev et al. [43]. A significant difference can also be seen in potassium. The measured concentration in CB corresponds to the data of Vassilev et al. [43], but it is about four times higher than the value reported by Free Company. Higher values in CB than those reported for coal lignite Clarke [59] were found for $\mathrm{Mn}$ and $\mathrm{Cr}$, while other trace elements, including As, have lower values.

Table 6. Content of inorganic elements in CB and their comparison with literature values and coal Clarke values.

\begin{tabular}{|c|c|c|c|c|c|c|c|c|c|c|c|c|c|c|c|c|c|}
\hline \multirow{2}{*}{$\begin{array}{l}\text { Coal } \\
\text { Briquette }\end{array}$} & $\mathrm{Al}$ & $\mathrm{Si}$ & $\mathrm{Ca}$ & $\mathrm{Mg}$ & $\mathrm{Fe}$ & $\mathrm{Ti}$ & $\mathbf{P}$ & $S$ & $\mathbf{K}$ & $\mathrm{Cl}$ & Mn & $\mathrm{Cr}$ & $\mathrm{Ni}$ & $\mathrm{Cu}$ & $\mathrm{Zn}$ & $\mathbf{P b}$ & As \\
\hline & \multicolumn{9}{|c|}{$\%$} & \multicolumn{8}{|c|}{$\mathrm{mg} / \mathrm{kg}$} \\
\hline $\begin{array}{l}\text { CB, } \\
\text { REKORD } 4 \\
\text { REKORD } 4\end{array}$ & 0.9 & 2.08 & 0.54 & & 0.46 & 0.14 & 0.024 & 0.22 & 0.11 & 86 & 273 & 33 & 24 & 19 & 22 & 10 & 2.54 \\
\hline $\begin{array}{l}\text { Free } \\
\text { Company, } \\
\text { s.r.o. }\end{array}$ & 0.07 & 0.23 & 1.14 & 0.17 & 0.50 & & & 0.2 & 0.03 & & & & & & & & \\
\hline $\begin{array}{l}\text { Lignite * } \\
\text { Lignite ** }\end{array}$ & $\begin{array}{l}0.71 \\
0.74\end{array}$ & 3.04 & $\begin{array}{l}0.79 \\
1.86\end{array}$ & $\begin{array}{l}0.20 \\
0.11\end{array}$ & $\begin{array}{l}0.56 \\
0.67\end{array}$ & $\begin{array}{l}0.07 \\
0.03\end{array}$ & 0.0068 & 0.54 & $\begin{array}{l}0.11 \\
0.04\end{array}$ & $\begin{array}{l}41.5 \\
120\end{array}$ & $\begin{array}{c}86 \\
72.7\end{array}$ & 13.3 & 32 & 19.5 & 28 & ND & 1.77 \\
\hline $\begin{array}{l}\text { Coal clark } \\
\text { lignite *** }\end{array}$ & & & & & & 0.072 & 0.02 & & & & 100 & 15.0 & 9.0 & 15 & 18 & 6.6 & 7.6 \\
\hline Lignite **** & 1.5 & & 0.46 & 0.11 & 1.30 & 0.08 & 0.043 & & 0.18 & & 43 & 15.0 & 14 & 16 & 53 & 11 & 24 \\
\hline
\end{tabular}

Explanations: * Vassilev et al. [43], ${ }^{* *}$ Tomza and Kaleta [60], ${ }^{* * *}$ Ketris and Yudovich [59], ${ }^{* * * *}$ Finkelman et al. [56].

The highest levels of major and trace elements $\mathrm{Al}, \mathrm{Si}, \mathrm{Fe}, \mathrm{Ti}, \mathrm{Cr}$, and $\mathrm{Ni}$ were found in $\mathrm{CB}>\mathrm{PB}>\mathrm{WM}$. The highest levels for $\mathrm{Ca}, \mathrm{K}, \mathrm{Mn}, \mathrm{Cu}$, and $\mathrm{Pb}$ were found in $\mathrm{PB}>\mathrm{WM}>\mathrm{CB}$, while for $\mathrm{P}$ and $\mathrm{Zn}$ elements, the highest levels were found in $\mathrm{WM}>\mathrm{PB}>\mathrm{CB}$.

\subsection{Elements in Ash and Deposit}

The behaviour of trace elements during combustion depends on their concentration, the form of occurrence, and how they are bonded to the organic or inorganic components of the coal and the combustion conditions [61]. Elements bonded in organic matter are vaporised and subsequently escape into the atmosphere or are adsorbed on small particles of ash during combustion in the boiler. Most elements that have a higher affinity for the inorganic matrix are usually non-volatile and tend to stay in the ash or fly ash [62].

Vassilev et al. [43] sorted the elements by the concentration of ash-forming elements in plant ash (141 biomass varieties) in the following order: $\mathrm{O}>\mathrm{Ca}>\mathrm{K}>\mathrm{Si}>\mathrm{Mg}>\mathrm{Al}>\mathrm{Cl}$ $>\mathrm{P}>\mathrm{Fe}>\mathrm{Na}>\mathrm{S}>\mathrm{Mn}>\mathrm{Ti}$. Elements $\mathrm{Ca}, \mathrm{Cl}, \mathrm{K}, \mathrm{Mg}, \mathrm{Mn}, \mathrm{Na}, \mathrm{P}$, and $\mathrm{S}$ in ash from natural biomass normally show higher contents than the respective values for coal ashes, while $\mathrm{Al}$, $\mathrm{Fe}, \mathrm{Si}$, and Ti show significantly lower values [43].

Based on the concentrations of major elements in ash from WM briquette combustion, the elements show a similar arrangement of $\mathrm{Ca}>>\mathrm{Si}=\mathrm{K}>\mathrm{Fe}>\mathrm{Al}>\mathrm{Mn}>\mathrm{S}>\mathrm{P}>\mathrm{Ti}$ as elements in ash from plant ash [43]. The series of trace elements in ash from WM burning is as follows, according to trace element concentration: $\mathrm{Zn}>\mathrm{Cl}>\mathrm{Cu}>\mathrm{Pb}>\mathrm{Ni}=\mathrm{Cr}$ $=$ As. Calcium levels in ash are up to five times higher than those of $\mathrm{Si}$, a ratio that is maintained in deposits. The ash from WM has a significantly higher Fe content than plant ash [43]. Differences in Fe content are already evident in WM briquettes, which contain up to 15 times more Fe than wood biomass, according to Jensen et al. [63]. In addition, 
Si has about nine times higher content in $\mathrm{WM}$, and $\mathrm{Al}$ up to twenty times higher content than Jensen et al. [63] reported for wood. Increased $\mathrm{Fe}$, $\mathrm{Al}$, and $\mathrm{Si}$ concentrations may be related to the brushing of furniture wood. Garnet, aluminium oxide, silicon carbide and alumina-zirconia are used as abrasives.

When comparing the concentrations of elements in fuel (Table 7) and ash, the position of $P$ has changed because it is highly volatile. The order of trace elements in ash has remained unchanged compared to the input fuel.

Table 7. Concentration of major and trace elements in ash and deposit (arithmetic mean and standard deviation).

\begin{tabular}{|c|c|c|c|c|c|c|c|c|c|c|c|c|c|c|c|c|c|}
\hline & \multirow{2}{*}{ Samples } & Al & $\mathrm{Si}$ & $\mathrm{Ca}$ & $\mathrm{Fe}$ & Mn & $\mathrm{Ti}$ & $\mathbf{P}$ & $S$ & $\mathbf{K}$ & $\mathrm{Cr}$ & $\mathrm{Ni}$ & $\mathrm{Cu}$ & $\mathrm{Zn}$ & As & $\mathrm{Pb}$ & $\mathrm{Cl}$ \\
\hline & & \multicolumn{9}{|c|}{$(\%)$} & \multicolumn{7}{|c|}{$\mathrm{mg} / \mathrm{kg}$} \\
\hline AVG & BEC2 & 3.42 & 6.53 & 30.9 & 0.58 & 0.04 & 0.34 & 0.25 & 0.23 & 0.17 & 12.0 & 25.9 & 246 & 207 & 2.9 & 34.6 & 179 \\
\hline STD & PB-A & 0.67 & 1.12 & 12.3 & 0.17 & 0.01 & 0.12 & 0.08 & 0.04 & 0.05 & 3.5 & 11.3 & 82.8 & 38.0 & 0.6 & 11.1 & 28.6 \\
\hline AVG & BEC3 & 2.33 & 6.29 & 32.8 & 0.48 & 0.17 & 0.36 & 0.34 & 0.28 & 0.34 & 30.0 & 24.5 & 221.9 & 171 & 6.2 & 56.9 & 462 \\
\hline STD & PB-A & 0.46 & 1.34 & 14.1 & 0.14 & 0.08 & 0.17 & 0.06 & 0.07 & 0.11 & 7.6 & 8.3 & 75.1 & 41.8 & 1.4 & 17.4 & 157 \\
\hline AVG & BEC2 & 0.50 & 2.70 & 11.8 & 0.76 & 0.11 & 0.15 & 0.20 & 1.08 & 0.93 & 14.0 & 22.0 & 100.2 & 410 & 12.8 & 109 & 6000 \\
\hline STD & PB-D & 0.21 & 0.39 & 3.13 & 0.24 & 0.01 & 0.02 & 0.02 & 0.21 & 0.21 & 3.2 & 8.0 & 21.9 & 98.6 & 3.3 & 29.9 & 897 \\
\hline AVG & BEC3 & 0.42 & 1.09 & 6.14 & 0.84 & 0.21 & 0.05 & 0.16 & 0.98 & 0.97 & 14.0 & 27.5 & 72.5 & 392 & 11.0 & 91.9 & 1460 \\
\hline STD & PB-D & 0.12 & 0.33 & 1.44 & 0.31 & 0.02 & 0.015 & 0.02 & 0.17 & 0.29 & 2.6 & 5.2 & 10.6 & 87.5 & 2.9 & 18.7 & 350 \\
\hline AVG & BEC2 & 1.14 & 2.32 & 21.7 & 1.97 & 0.43 & 0.14 & 0.28 & 0.35 & 2.36 & 31.0 & 31.0 & 245 & 938 & 39.0 & 104 & 779 \\
\hline STD & WM-A & 0.44 & 0.51 & 1.82 & 0.70 & 0.14 & 0.04 & 0.02 & 0.08 & 0.62 & 8.2 & 8.24 & 83.5 & 280 & 4.4 & 11.2 & 77.2 \\
\hline AVG & BEC3 & 1.24 & 3.11 & 12.8 & 2.17 & 0.34 & 0.19 & 0.28 & 0.33 & 2.67 & 48.0 & 57.0 & 221 & 2000 & 58.0 & 102 & 1217 \\
\hline STD & WM-A & 0.19 & 0.40 & 1.21 & 0.44 & 0.12 & 0.05 & 0.03 & 0.14 & 0.56 & 15.0 & 12.0 & 64.4 & 457 & 8.0 & 7.8 & 115 \\
\hline AVG & BEC2 & 0.6 & 1.57 & 10.7 & 1.99 & 0.57 & 0.06 & 0.58 & 3.09 & 5.48 & 7.0 & 15.5 & 135 & 3000 & 43.0 & 202 & 2867 \\
\hline STD & WM-D & 0.37 & 0.62 & 3.02 & 0.50 & 0.14 & 0.01 & 0.15 & 1.20 & 0.83 & 1.40 & 1.53 & 48.8 & 785 & 8.7 & 34.5 & 341 \\
\hline AVG & BEC3 & 0.57 & 1.33 & 5.41 & 1.96 & 0.25 & 0.18 & 0.28 & 1.71 & 3.73 & 24.0 & 12.0 & 149 & 6700 & 35.0 & 365.0 & 6989 \\
\hline STD & WM-D & 0.07 & 0.14 & 0.50 & 0.36 & 0.02 & 0.03 & 0.02 & 0.30 & 0.18 & 8.3 & 4.56 & 32.0 & 921 & 7.3 & 86.3 & 759 \\
\hline AVG & BEC2 & 8.10 & 13.92 & 7.60 & 7.27 & 0.30 & 0.98 & 0.57 & 2.27 & 1.19 & 149 & 149 & 258 & 337 & 4.1 & 47.6 & 870 \\
\hline STD & CB-A & 1.17 & 1.25 & 2.49 & 2.35 & 0.02 & 0.32 & 0.21 & 0.51 & 0.41 & 19.4 & 13.1 & 72.7 & 126 & 1.0 & 12.8 & 98.5 \\
\hline AVG & BEC3 & 7.16 & 13.07 & 6.78 & 8.36 & 0.15 & 0.90 & 0.49 & 2.72 & 1.23 & 174. & 158 & 302 & 409 & 4.8 & 45.5 & 750 \\
\hline STD & CB-A & 0.48 & 0.36 & 1.04 & 1.40 & 0.03 & 0.12 & 0.05 & 0.38 & 0.18 & 17.7 & 13.3 & 107 & 99.4 & 0.6 & 15.9 & 87.5 \\
\hline AVG & BEC2 & 1.02 & 1.89 & 13.3 & 7.51 & 0.20 & 0.06 & 0.17 & 6.46 & 1.48 & 74.2 & 36.0 & 47.8 & 451 & 11.0 & 37.3 & 3026 \\
\hline STD & CB-D & 0.28 & 0.42 & 3.22 & 1.95 & 0.05 & 0.02 & 0.06 & 1.29 & 0.72 & 16.5 & 11.3 & 12.4 & 116 & 2.3 & 12.8 & 824 \\
\hline AVG & BEC3 & 0.36 & 0.66 & 4.14 & 5.93 & 0.23 & 0.05 & 0.16 & 3.11 & 1.29 & 89.0 & 44.0 & 52.0 & 969 & 9.7 & 79.7 & 1389 \\
\hline STD & CB-D & 0.06 & 0.12 & 0.75 & 0.70 & 0.03 & 0.04 & 0.02 & 0.32 & 0.16 & 18.4 & 12.3 & 6.42 & 22.0 & 2.5 & 8.7 & 428 \\
\hline
\end{tabular}

\subsection{Release of Elements into the Atmosphere during Combustion}

The amounts of element release were quantified by a mass balance based on weight measurements and chemical analysis of the fuel and ash obtained, similarly to Sommersacher et al. [64]. The calculation was made on the basis of data on the total amount of fuel burned and the concentrations of elements in the fuel, the amounts of by-products of combustion, and the concentrations of elements captured in deposits and ash. The results, expressed as the percentage of the element released into the atmosphere from the burnt fuel, are highly relevant to the assessment of the environmental performance of domestic boilers (Figure 3). The amounts of elements captured in ash are shown in Table 8. Due to the small production and collection of particles in deposits (Table 2), the amounts of the captured elements are low. For $\mathrm{PB}$ and $\mathrm{CB}$, the amounts of elements captured are $<1 \%$ except for $\mathrm{Cl}$ and $\mathrm{Zn}(2.3 \%)$ for CB. In the case of WM, the production of deposits per $\mathrm{kg} /$ fuel was higher $(8-10 \mathrm{~g} / \mathrm{kg})$, and the capture of elements is more significant, ranging between $10-15 \%$.

Table 8. Amounts of elements contained in ash (\%)—calculated from mass balance.

\begin{tabular}{|c|c|c|c|c|c|c|c|c|c|}
\hline & $<10$ & $10-20$ & $20-30$ & $30-40$ & $40-50$ & $50-60$ & $60-70$ & $70-80$ & $>80$ \\
\hline PB & & $\mathrm{K}, \mathrm{S}, \mathrm{Cl}, \mathrm{Zn}, \mathrm{As}$ & $\mathrm{Mn}$ & $\mathrm{Fe}, \mathrm{P}, \mathrm{Cr}, \mathrm{Ni}$ & $\mathrm{Si}, \mathrm{Ti}$ & $\mathrm{Al}, \mathrm{Ca}, \mathrm{Cu}$ & & & \\
\hline WM & $\mathrm{P}$ & $\mathrm{Al}, \mathrm{Si}, \mathrm{Ni}, \mathrm{Zn}$ & $\mathrm{Ti}, \mathrm{S}, \mathrm{Cr}$ & $\begin{array}{l}\mathrm{Fe}, \mathrm{K}, \mathrm{Cl}, \mathrm{Mn}, \\
\quad \mathrm{Cu}, \mathrm{Pb}\end{array}$ & & $\mathrm{Ca}, \mathrm{As}$ & & & \\
\hline $\mathrm{CB}$ & As & & $\mathrm{Cr}, \mathrm{Pb}$ & $\mathrm{Si}, \mathrm{Ti}, \mathrm{Ni}$ & $\mathrm{Al}$ & $\mathrm{K}, \mathrm{Cl}, \mathrm{Mn}$ & S & $\begin{array}{c}\mathrm{Ca}, \mathrm{P}, \\
\mathrm{Cu}\end{array}$ & $\mathrm{Fe}, \mathrm{Zn}$ \\
\hline
\end{tabular}

The binding of elements in ash and their release into the atmosphere is primarily influenced by the form of the element in the fuel, which is probably more significant in terms of their release into the environment than the technological solution of domestic boilers. 


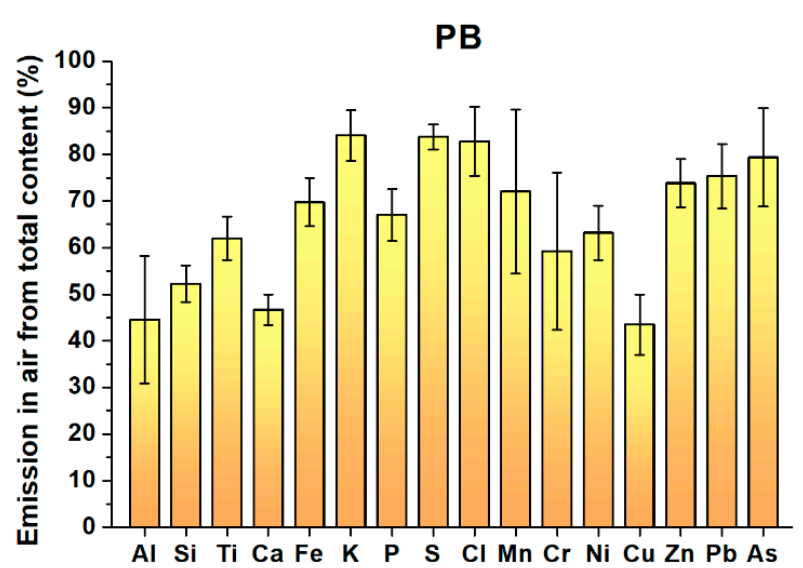

(a)

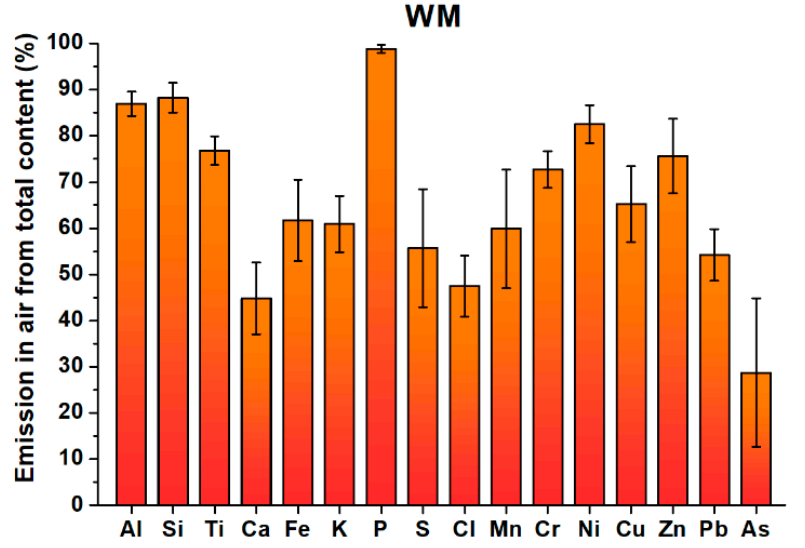

(b)

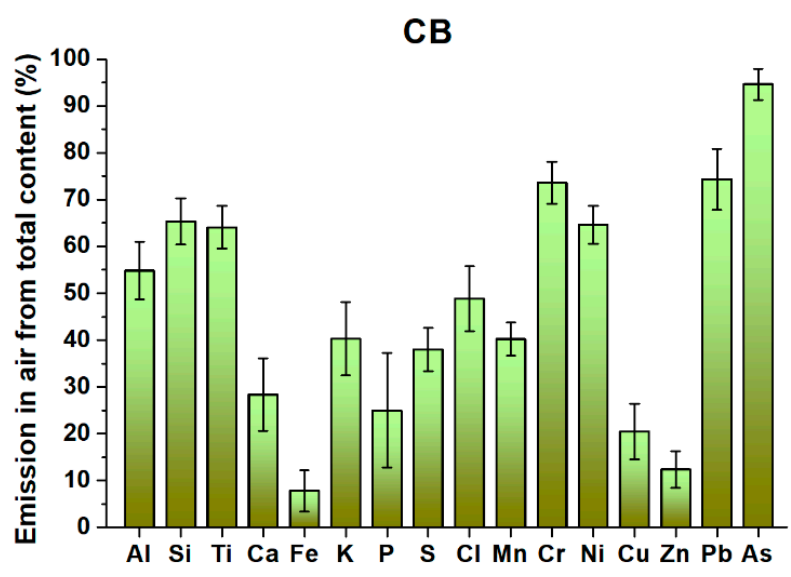

(c)

Figure 3. Amounts of elements emitted during combustion from the stack expressed as a proportion of the total amount of elements contained in the burnt fuel (calculated from the values for both BEC2 and BEC3)-(a) paper briquettes PB, (b) briquettes from waste wood WM, (c) coal briquettes CB.

The most significant amounts of the major elements $\mathrm{Al}, \mathrm{Si}, \mathrm{Ti}$, and $\mathrm{P}$ are released into the atmosphere from WM. The largest amounts of $\mathrm{Ca}, \mathrm{Fe}, \mathrm{S}, \mathrm{K}$, and $\mathrm{Cl}$ are released into the atmosphere from PB. Major elements are released in the lowest amounts from CB (Figure 3). Of the trace elements, the most significant amounts of $\mathrm{Ni}$. The largest amounts of $\mathrm{Cu}$ and $\mathrm{Zn}$ are released from $\mathrm{WM}$. The largest amounts of $\mathrm{Mn}$ and $\mathrm{Pb}$ are released from paper briquettes (PB). The largest amounts of $\mathrm{As}$ and $\mathrm{Cr}$ are released from $\mathrm{CB}$. These results correspond to the mass balances from the joint evaluation of the two boilers, which were similar for both BEC2 and BEC3. Cases with a difference in the amounts of elements released into the atmosphere for the compared boilers $>20 \%$ are shown in Table 9.

Table 9. Relative differences in the amounts of the element released into the atmosphere resulting from a comparison between the combustion equipment.

\begin{tabular}{cccccc}
\hline & PB & & & CD \\
\hline BEC2 > BEC3 & BEC3 > BEC2 & BEC2 > BEC3 & BEC3 > BEC2 & BEC2 > BEC3 & BEC3 > BEC2 \\
\hline & $\begin{array}{c}\mathrm{Al}(45 \%), \mathrm{Mn} \\
(60 \%), \mathrm{Cr}(70 \%)\end{array}$ & $\mathrm{Ca}(25 \%)$, As $(65 \%)$ & $\mathrm{S}(51 \%), \mathrm{Mn}(32 \%)$ & $\mathrm{Fe}(56 \%)$, & $\mathrm{Cu}(47 \%), \mathrm{Zn}(36 \%)$ \\
\hline
\end{tabular}

The higher amount of $\mathrm{Al}$ released from the BEC3 boiler is probably related to the higher temperature that allows the decomposition of aluminium sulfate used in the production of surface treatment paper, which decomposes at $770-860{ }^{\circ} \mathrm{C}$ [65]. Manganese (Mn) in 
biomass occurs as positive metal ions, which can be in the form of free ions or complexes. Metal ions may also be organically associated with biomass fibres [52] and can only be released into the air when they burn out.

The higher amount of Ca released from the BEC2 boiler during WM combustion is related to the degradation of calcium oxalate crystals [66] and the subsequent reaction of $\mathrm{Ca}$ ions with $\mathrm{CO}_{2}$ to form calcite at $>479{ }^{\circ} \mathrm{C}$. Calcite decomposes at a temperature higher than $750{ }^{\circ} \mathrm{C}$ [67] for the creation of $\mathrm{CaO}$. $\mathrm{CaO}$ has not been identified in ash and deposit products from $\mathrm{BEC} 2$ and $\mathrm{BEC} 3$ by the X-ray-diffraction method. The mineralogical analysis of ash shows that in the case of ash and deposits from BEC3, a greater amount of $\mathrm{Ca}$ is bound in an amorphous phase, which was formed at a higher temperature than was present in the BEC2 boiler. A surplus of Ca ions was released into the atmosphere. Wood preservatives containing As (arsenate) break down in the temperature range from $750-800{ }^{\circ} \mathrm{C}$ during dearsenation [68]. The amount of sulfur in the BEC2 and BEC 3 boiler emissions is affected by the thermal degradation of thioxanthene, which has been identified in the deposit products and in the input material by the Py-GC/MS method. Thioxanthene is a pyrolysis product formed by the thermal degradation of the thiophenol/formaldehyde resins [69] contained in WM. In addition to thioxanthene, other sulfur-containing organic compounds have been identified in the deposits from BEC2 from WM combustion - thiourea, tetramethyl thiourea, 3 methyl thiophene and dihydro 2,3H thiophenone, which are also produced during the thermal degradation of thiophenol/formaldehyde resins. For example, thiourea starts to isomerize to ammonium thiocyanate $\left(\mathrm{NH}_{4} \mathrm{SCN}\right)$ at temperatures ranging from 140 to $180{ }^{\circ} \mathrm{C}$ [70]. The absence of these compounds in deposits from BEC3 explains the degradation of sulfur-containing organic compounds in the BEC 3 boiler, and hence the higher sulfur emissions.

Results of the mineralogical analysis were also used to identify the differences between element release during the combustion of $\mathrm{CB}$ in BEC2 and BEC3. The results indicate that the amounts of maghemite in deposits from BEC2 $(13.45 \%)$ and BEC3 $(20.45 \%)$ vary significantly. In addition, hematite is also present in BEC3 (8.68\%). Maghemite levels in ash from the combustion in both BEC2 and BEC3 are comparable (14.55 and 16.31\%). Generally, higher amounts of Fe are bound in deposits from BEC3 in mineral Fe-phases than in BEC2. During combustion, iron distribution into individual phases-hematite, magnetite and Fe-glass phases-is affected by the $\mathrm{O}_{2} / \mathrm{CO}_{2}$ ratio [71]. With a higher $\mathrm{O}_{2} / \mathrm{CO}_{2}$ concentration, the proportion of magnetite increases and hematite decreases, while the amount of Feglass phase does not change. The amount of unburned carbon affects oxidation processes involving the formation of magnetite, maghemite, and hematite. After the complete burning of carbon, the magnetite present in the ash becomes completely oxidised to hematite [72]. Part of hematite and magnetite (approximately $8 \%$ of $\mathrm{Fe}$ ) crystallises from the molten glass phases during combustion and is not significantly affected by changing combustion conditions [71]. Some trace elements are bonded to newly formed Fe-phases when coal is burned. For the deposits from BEC2 and BEC3, a polynomial dependence between $\mathrm{Fe}$ and $\mathrm{Cu}$ concentration was confirmed $(\mathrm{r}=0.84, n=9, \alpha=0.005)$. Adsorption of heavy metals on the surface of iron oxides (mainly magnetite) in preferential order of $\mathrm{Pb}$, $\mathrm{Zn}, \mathrm{Cu}, \mathrm{Cr}$, and $\mathrm{Cd}$ or their substitution in minerals with spinel structure is known [73]. In the case of $\mathrm{Zn}$, correlation between $\mathrm{Zn}$ and Ca has been demonstrated ( $\mathrm{r}=0.81, n=9$, $\alpha=0.01$ ).

Differences in the behaviour of both major and trace elements during the combustion in BEC2 and BEC3 are primarily due to the presence of elements in the input fuel and the decomposition ability of phases in which both major and trace elements are bound and influenced by temperature and oxidation-reduction conditions.

In recalculation on the element content of the input fuel, up to twice as many major elements $(55 \mathrm{~g} / \mathrm{kg})$ were released from PB during combustion compared to WM $(28 \mathrm{~g} / \mathrm{kg}$ fuel for BEC2 and $19 \mathrm{~g} / \mathrm{kg}$ for BEC3) and CB (BEC2 $21 \mathrm{~g} / \mathrm{kg}$ and BEC3 $23 \mathrm{~g} / \mathrm{kg}$ ). Calcium (up to $37 \mathrm{~g} / \mathrm{kg}$ of fuel) accounts for the major proportion of elements released when $\mathrm{PB}$ is burned (Figure 4). The concentration of emitted elements when burning PB decreases 
in the following order: $\mathrm{Si}>\mathrm{Al}>\mathrm{Ca}>\mathrm{Ti}>\mathrm{S}>\mathrm{K}=\mathrm{Fe}>\mathrm{P}$, and for trace elements: $\mathrm{Mn}$ $>\mathrm{Cl}>\mathrm{Zn}>\mathrm{Cu}>\mathrm{Pb}>\mathrm{Ni}=\mathrm{Cr}=$ As. The high sulphur emissions from burning $\mathrm{PB}$ are due to the presence of organically bound sulfur, which is part of lignin sulfonate, a byproduct of the sulfite pulping process [74] used to glue cartons [75]. The thermal stability of sulfonic groups is rather weak, as indicated by the low-temperature evolution of $\mathrm{SO}_{2}$. The decomposition is done in two stages at a temperature of between 120 and $360^{\circ} \mathrm{C}$, and the lignin component [76] decomposes from 360 to $700{ }^{\circ} \mathrm{C}$. Cations $\left(\mathrm{Na}^{+}\right.$and $\left.\mathrm{NH}_{4}{ }^{+}\right)$bonded to the sulphonic groups strongly affect the decomposition of lignosulphonates. In the case of sodium sulfonate, sulphur is bound to $\mathrm{Na}_{2} \mathrm{SO}_{3}, \mathrm{or} \mathrm{Na}_{2} \mathrm{SO}_{4}$ and sulfides are formed under reduction conditions. The sulfonic group with $\mathrm{NH}_{4}{ }^{+}$releases $\mathrm{NH}_{3}$ at $270{ }^{\circ} \mathrm{C}$, breaking down the sulfonate group into $\mathrm{SO}_{2}$ [76].

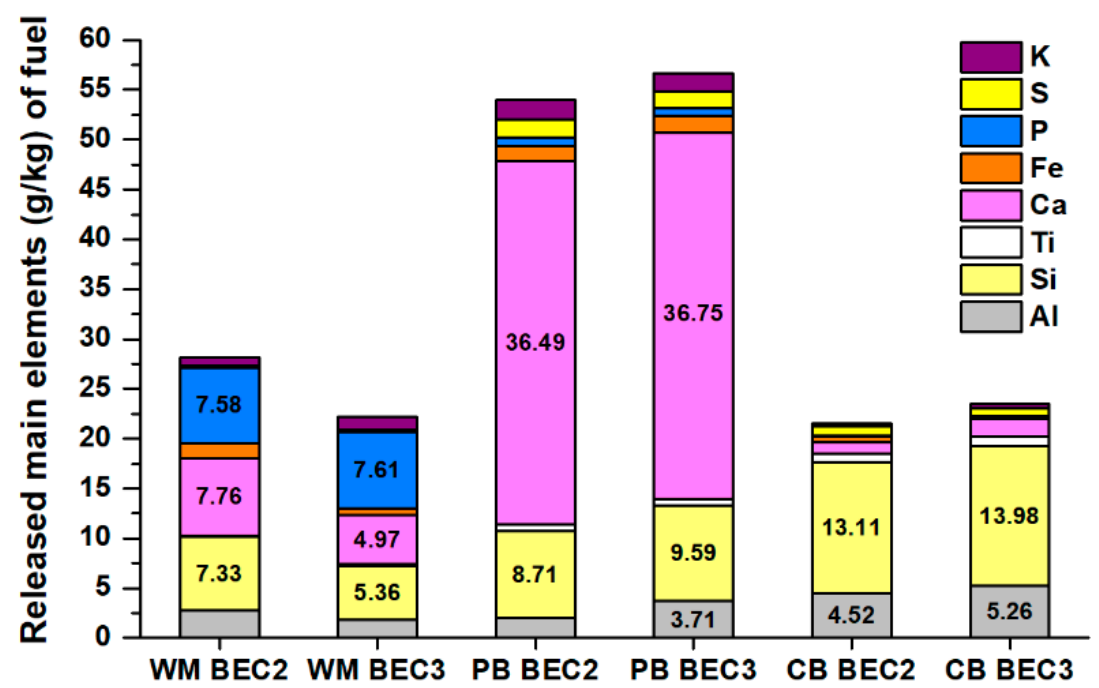

Figure 4. Major elements ( $\mathrm{Al}, \mathrm{Si}, \mathrm{Ti}, \mathrm{Fe}, \mathrm{Ca}, \mathrm{S}, \mathrm{K}$, and $\mathrm{P}$ ) released from the burning of $1 \mathrm{~kg}$ of fuel in $\mathrm{BEC} 2$ and $\mathrm{BEC} 3$.

The comparison of individual fuels shows that when burning PB, $1 \mathrm{~kg}$ of fuel releases the highest amount of trace elements $630-830 \mathrm{mg} / \mathrm{kg}$ (Figure 5). The value is affected by a high concentration of $\mathrm{Mn}$. Other monitored elements ( $\mathrm{As}, \mathrm{Cu}, \mathrm{Cr}, \mathrm{Ni}, \mathrm{Pb}$, and $\mathrm{Zn}$ are emitted at a concentration of $121-128 \mathrm{mg} / \mathrm{kg}$, which is lower than WM combustion emissions. In the case of printed cartons, the content of other elements of $\mathrm{Sn}$ and $\mathrm{Sb}$ is also increased in the flue gas [77]. The amounts of trace elements released when burning waste office paper and corrugated cardboard increases with temperature [78]. When burning waste paper at $750-950{ }^{\circ} \mathrm{C}$, manganese $(68-205 \mathrm{mg} / \mathrm{kg}$ of fuel) and lead $(38-54 \mathrm{mg} / \mathrm{kg}$ of fuel) pass into flue gas [78]. In our case, the amount of Mn released into the air was about twice as high, with input paper briquettes containing $\mathrm{Mn}$ in concentrations up to $520 \mathrm{mg} / \mathrm{kg}$. The combustion in the EC2 and EC3 boiler released Mn in amounts of 300 to $470 \mathrm{mg} / \mathrm{kg}$ of fuel and $\mathrm{Pb}$ in amounts of 18 to $20 \mathrm{mg} / \mathrm{kg}$ of fuel. Lead and zinc have a lower volatility of $\mathrm{Zn}$ during the combustion of waste paper at a lower rate of combustion. The behaviour of $\mathrm{Cu}$ is not affected by the rate of combustion [79]. When burning WM in $\mathrm{BEC} 2$ at the fuel ratios $2.5 \mathrm{~kg} / \mathrm{h}$ and $4 \mathrm{~kg}$ fuel $/ \mathrm{h}$ (BEC3), the differences in $\mathrm{Cu}, \mathrm{Pb}$, and $\mathrm{Zn}$ emitted were not significant.

When burning WM, the series of released elements is $\mathrm{P}>\mathrm{Si}>\mathrm{Ca}>\mathrm{Al}>\mathrm{Fe}>\mathrm{K}>\mathrm{S}$ $>\mathrm{Ti}$, and for trace elements: $\mathrm{Mn}>\mathrm{Cl}>\mathrm{Zn}>\mathrm{Cu}>\mathrm{Ni}>\mathrm{Pb}>\mathrm{Ni}=\mathrm{Cr}=$ As. Phosphorus was released in the highest amounts; it can be completely released as gaseous phosphorus oxides during the combustion process when it is organically bound due to the high volatility of organic phosphorus compounds [80,81]. Potassium release into the air from burning waste wood was studied by Sommersacher et al. [64], who found lower amounts of $\mathrm{K}$ release for waste wood $(18.5 \pm 3.2 \%)$, hardwood chips $(32.8 \pm 12.0 \%)$, and softwood chips $(24.9 \pm 8.1 \%)$ than was demonstrated for the PB burning (54-56\%). The contamination 
caused by the presence of soil particles in biomass in the feedstock also affects potassium behaviour during the combustion process of compressed wood mass, where $\mathrm{K}$ is bound in silicate minerals, and thus the amount of produced $\mathrm{K}_{2} \mathrm{SO}_{4}$ is decreased, resulting in an increase in $\mathrm{SO}_{\mathrm{x}}$ emissions [54].

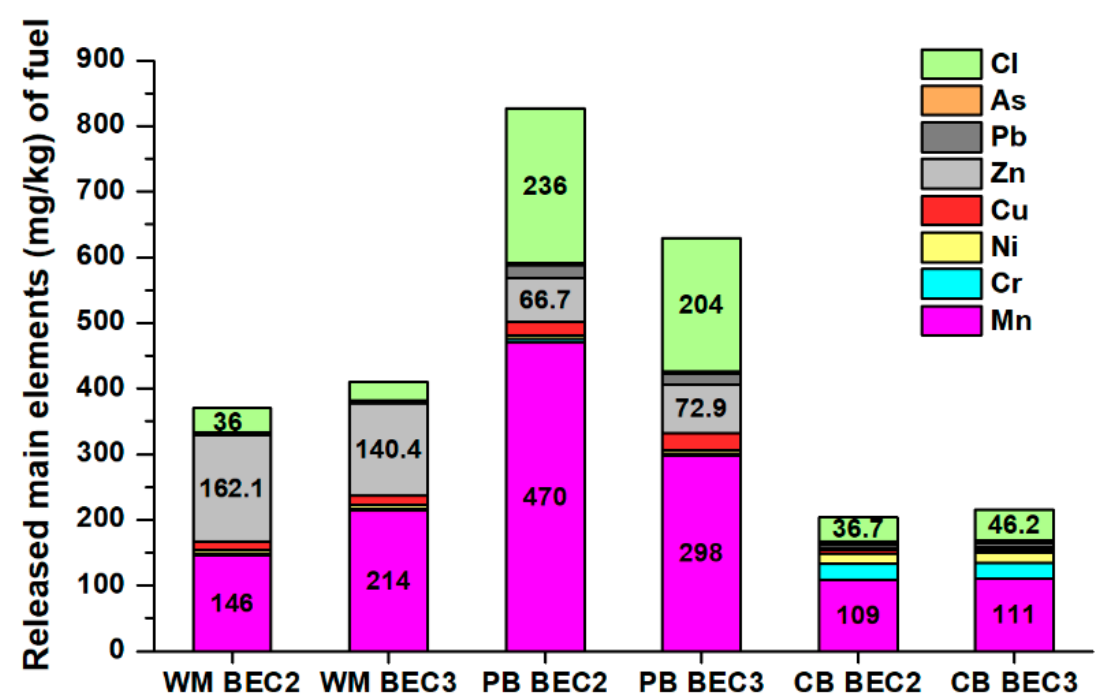

Figure 5. Trace elements ( $\mathrm{As}, \mathrm{Cr}, \mathrm{Cu}, \mathrm{Mn}, \mathrm{Ni}, \mathrm{Pb}$, and $\mathrm{Zn}$ ) with chlorine released from the burning of $1 \mathrm{~kg}$ of fuel.

According to decreasing concentrations, the different concentration series of major elements released into the atmosphere was found during burning CB. Due to silicates contained in the coal briquettes, the order of elements is as follows: $\mathrm{Si}>\mathrm{Al}>\mathrm{Ca}>\mathrm{Ti}>\mathrm{S}>$ $\mathrm{K}=\mathrm{Fe}>\mathrm{P}$, for trace elements $\mathrm{Mn}>\mathrm{Cl}>\mathrm{Cr}>\mathrm{Ni}>\mathrm{Cu}=\mathrm{Zn}=\mathrm{Pb}=$ As. The combustion of coal briquettes emits the lowest amounts of major elements (21-23 g/ kg), and for trace elements 204-215 mg/kg (with Mn), and about $58 \mathrm{mg} / \mathrm{kg}$ without $\mathrm{Mn}$. In terms of both major and trace element emissions, coal briquettes are a "cleaner" fuel than other fuels using waste products.

\subsection{Relative Enrichment Factor Elements in Ash and Deposits}

It is known from the literature that in the ash from coalburning, the concentration of trace elements increases with decreasing particle size, which is influenced by the specific surface and sorption processes [59,82]. Similar relationships are known for major elements (Ca, P, Mg, and $\mathrm{Si}$ ) in ash from biomass combustion but for $\mathrm{K}$, the opposite has been shown [43].

The highest amounts of fine-grained particles are present in samples of WM-D deposits, followed by PB-D (Figure 6). The comparison of the mean grain size $\left(\mathrm{d}_{050}\right)$ for WM-D $(0.114 \mathrm{~mm})$ and WM-A $(0.265 \mathrm{~mm})$ shows that the WM ash particles have a coarser character. $\mathrm{PB}$ combustion products show a similar trend. The mean particle size $\left(\mathrm{d}_{050}\right)$ for PB-D is $0.122 \mathrm{~mm}$, and for PB-A, it is $0.249 \mathrm{~mm}$. A completely different shape of particle size distribution curves was found for deposits from $C B$ combustion (Figure 7), where BEC3 CB-D has a mean grain value of $0.71 \mathrm{~mm}$ (specked particles are present), while BEC2 $\mathrm{CB}-\mathrm{D}$ has a mean grain size value of $0.42 \mathrm{~mm}$. The shapes of the ash grain curves are almost identical; the mean particle size for BEC2 CB-A is $0.254 \mathrm{~mm}$, and for BEC3 CB-A, it is $0.287 \mathrm{~mm}$. 


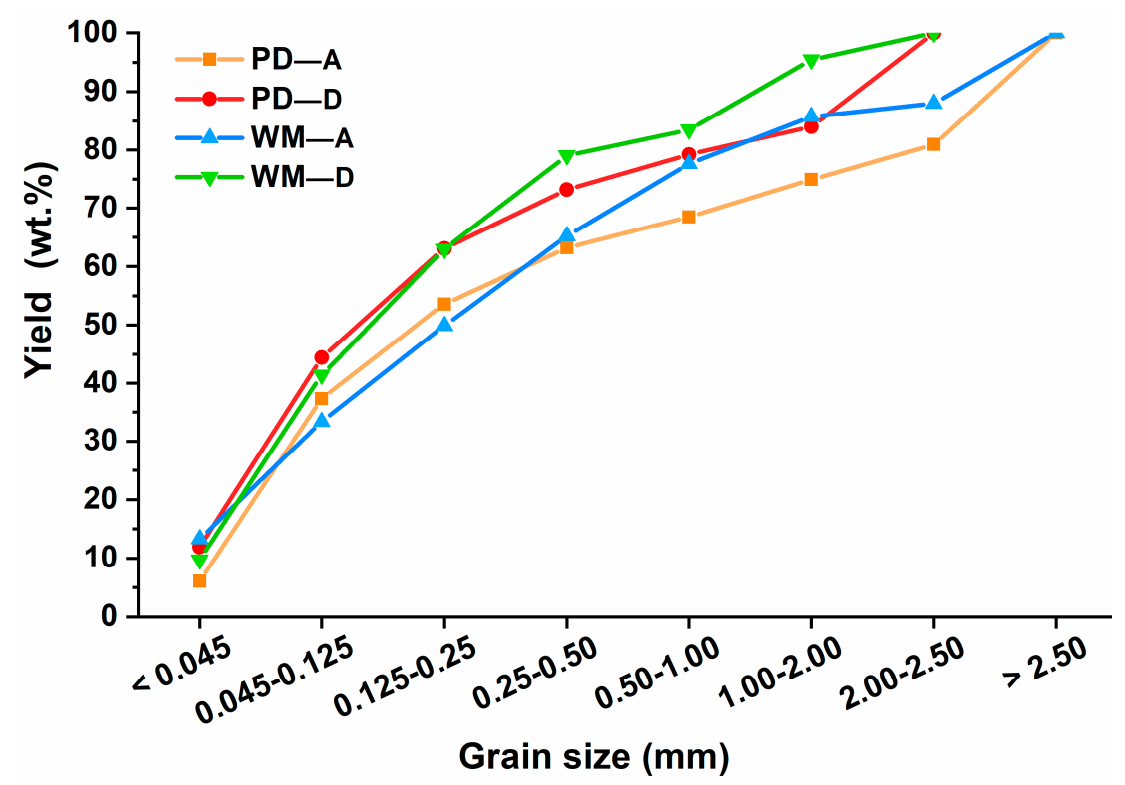

Figure 6. The grain size analysis of ash (A) and deposits (D), PB-A, PB-D and WM-A, WM-D.

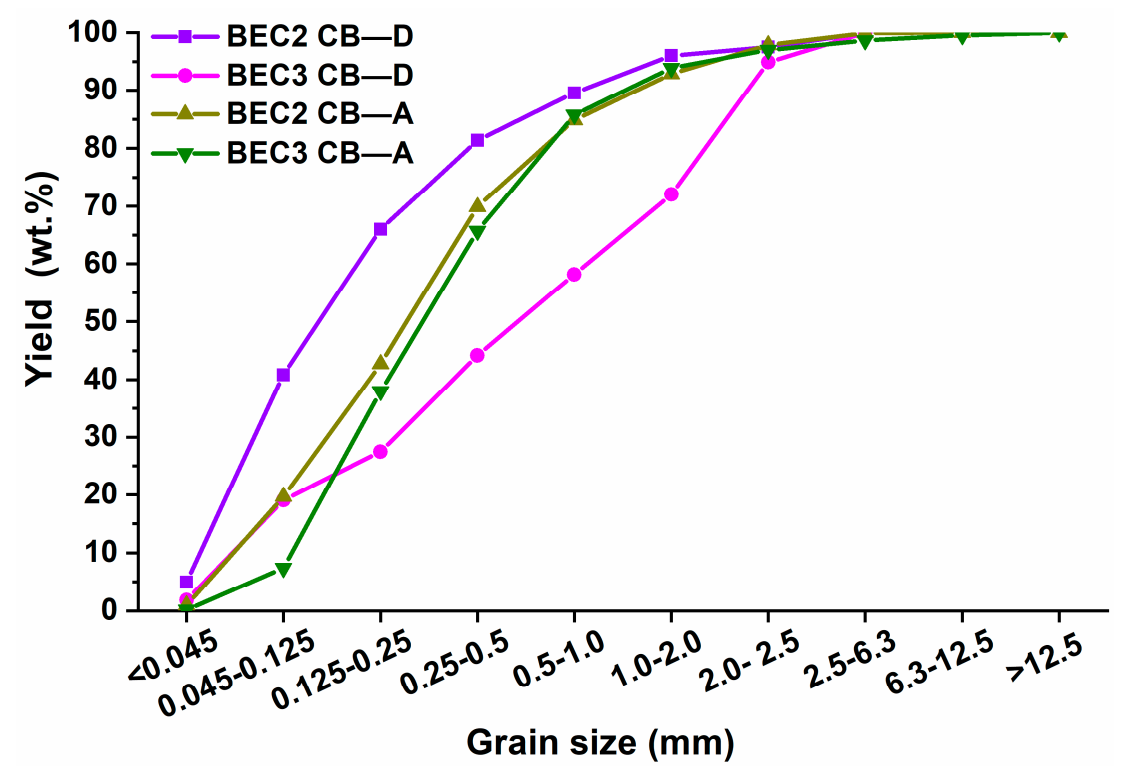

Figure 7. The grain size analysis of combustion products from coal briquettes.

The average size of the particles that make up the deposits is significantly smaller than the ash particles except for BEC3 CB-D. Therefore, it can be assumed that there could be enrichment by both major and trace elements, even in this case. The relative enrichment factor (RE) defined by Meij [83] was used to monitor the acquisition of by-products of combustion. Meij [83] classified trace elements contained in coal on the basis of the relationship between the temperature and degree of volatilisation during the combustion in large energy sources (Table 10).

During the combustion of $\mathrm{PB}$, higher values of RE were found for ash (except $S, \mathrm{Mn}$, and $\mathrm{Cl}$ ). When burning $\mathrm{CB}$, major elements $\mathrm{Al}, \mathrm{Si}$, Ti, and $\mathrm{Fe}$, and selected trace elements $\mathrm{Cr}, \mathrm{Ni}$ and $\mathrm{Cu}$ have higher values of $\mathrm{RE}$ in ash, while cations $\mathrm{Ca}$ and $\mathrm{K}$ and trace elements $\mathrm{Pb}, \mathrm{Zn}$, and As have higher values of RE in deposits (Figure 8). Completely different results were obtained when burning WM. All monitored elements (both major and trace) have a higher relative enrichment factor RE in deposits (Figure 9). The highest values were found for $\mathrm{Pb}$ and $\mathrm{Zn}$. 
Table 10. Comparison of elements characterised by the RE value according to the classification of Meij [83].

\begin{tabular}{|c|c|c|c|c|c|c|}
\hline & RE-BA & RE-FA & Meij [8? & & D-CB & D-WM \\
\hline Class I & ca. 1 & cca1 & $\begin{array}{l}\text { non-volatile elements, } \\
\text { equally distributed in } \\
\text { bottom ash and fly ash }\end{array}$ & $\begin{array}{c}\mathrm{Al}, \mathrm{Ca}, \mathrm{Ce}, \mathrm{Cs}, \\
\mathrm{Eu}, \mathrm{Fe}, \mathrm{Hf}, \\
\text { K, La, Mg, Sc, } \\
\mathrm{Sm}, \mathrm{Si}, \mathrm{Sr}, \mathrm{Th}, \mathrm{Ti}\end{array}$ & $\mathrm{Mn}, \mathrm{P}$ & \\
\hline \multirow[t]{3}{*}{ Class II } & $\begin{array}{l}<0.7 \\
\text { IIc }\end{array}$ & $1.3<\ldots<2$ & \multirow{3}{*}{$\begin{array}{l}\text { volatile in boiler but } \\
\text { condensation on ESP } \\
\text { ash particles }\end{array}$} & $\begin{array}{c}\mathrm{Ba}, \mathrm{Cr}, \mathrm{Mn}, \mathrm{Na}, \\
\mathrm{Rb}, \mathrm{Sr}\end{array}$ & $\mathrm{K}$ & Mn, As \\
\hline & $\mathrm{IIb}$ & $2<\ldots<4$ & & $\begin{array}{c}\mathrm{Be}, \mathrm{Co}, \mathrm{Cu}, \mathrm{Ni}, \\
\text { P, U, V, W }\end{array}$ & $\mathrm{S}, \mathrm{Ca}, \mathrm{Cl}$ & $\begin{array}{c}\mathrm{S}, \mathrm{Ca}, \mathrm{K}, \mathrm{Fe}, \mathrm{Ti}, \\
\mathbf{C u}\end{array}$ \\
\hline & IIa & $>4$ & & $\begin{array}{c}\text { As, Cd, Ge, Mo, } \\
\text { Pb, Sb, Tl, Zn }\end{array}$ & $\mathrm{Zn}, \mathrm{Fe}$ & $\mathrm{Zn}, \mathrm{Pb}, \mathrm{S}$ \\
\hline Class III & $<<1$ & & $\begin{array}{l}\text { very volatile without } \\
\text { condensation on ash } \\
\text { particles }\end{array}$ & $\begin{array}{l}\mathrm{B}, \mathrm{Br}, \mathrm{C}, \mathrm{Cl}, \mathrm{F} \\
\mathrm{Hg}, \mathrm{I}, \mathrm{N}, \mathrm{S}, \mathrm{Se}\end{array}$ & $\begin{array}{c}\mathrm{Cr}, \mathrm{Ni}, \mathrm{Cu}, \mathrm{Pb}, \\
\mathrm{As}\end{array}$ & $\mathrm{Al}, \mathrm{P}, \mathrm{Cr}, \mathrm{Ni}$ \\
\hline
\end{tabular}

Explanation: BA—Bottom ash; FA—Emissions of fly ash; bold—elements in accordance with the classification of Meij [83].

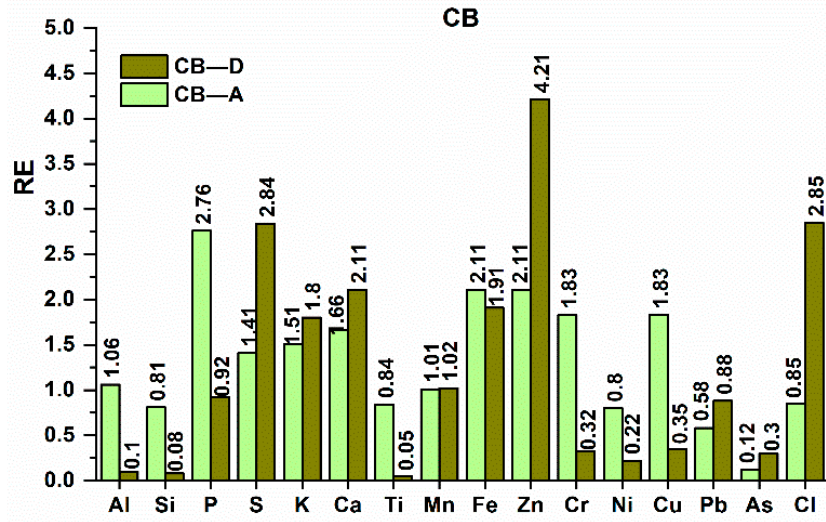

(a)

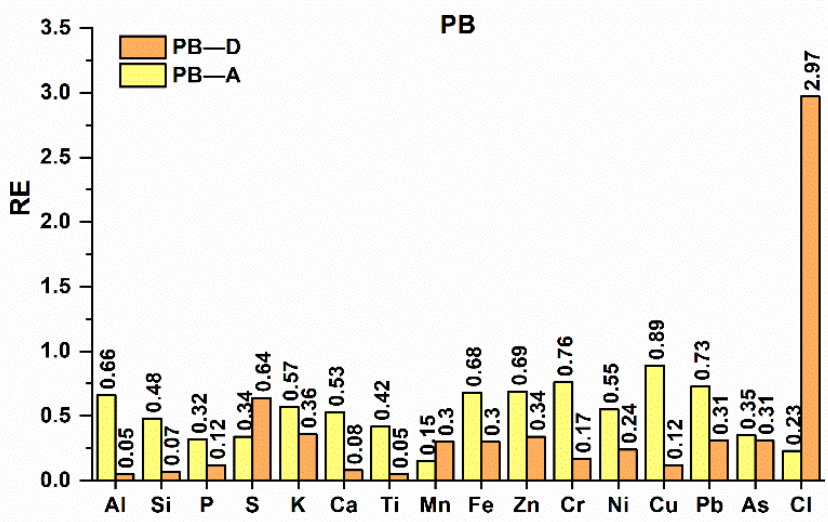

(b)

Figure 8. RE values for elements contained in ash and deposits from the combustion of $\mathrm{CB}(\mathbf{a})$ and $\mathrm{PB}(\mathbf{b})$; $\mathrm{RE}=\mathrm{Concentration}$ of element in ash/ash percentage in the feed coal $\times$ Concentrations of elements in coal/100.

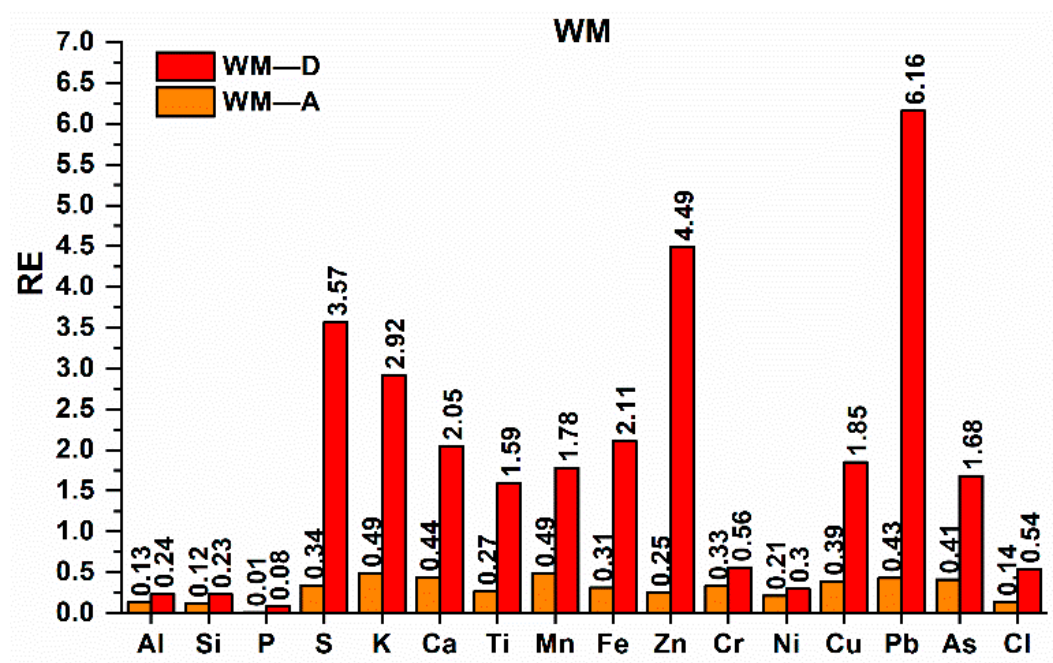

Figure 9. RE values for elements contained in ash and deposits from the combustion of WM.

Some regularities resulting from the behaviour of elements during the burning of coal [83] cannot be used to identify unauthorised fuels burned in domestic boilers for solid fuels, as documented by the results obtained from the burning of paper briquettes. 
In the case of $\mathrm{PB}$, all major elements and most trace elements (except $\mathrm{Cu}$ ) have $\mathrm{RE}<0.7$, placing them among the volatile elements. In fuels where elements occur bound in the form of salts, they are released into the atmosphere during combustion, which reduces their concentration in the by-products of combustion, and they cannot be used to identify the fuel originally burned. However, identification of unauthorised fuels on the basis of the presence of organic compounds in deposits is possible [26].

The ratios of the mean concentration values of elements in ash and deposits are shown in Figure 10. Ratio values $>1$ were found for $\mathrm{Al}, \mathrm{Si}, \mathrm{Ca}, \mathrm{Ti}, \mathrm{Cr}, \mathrm{Ni}, \mathrm{Cu}$, and $\mathrm{Fe}, \mathrm{Mn}(\mathrm{CB}$ and $\mathrm{WM}$ only), and $\mathrm{P}$ (PB and $\mathrm{CB}$ only). The values of $\mathrm{A} / \mathrm{D}$ concentration ratio $>1$ confirm that the element is preferentially bound to ash. The other elements $(\mathrm{S}, \mathrm{K}, \mathrm{Zn}, \mathrm{Pb}, \mathrm{Cl}$, and $\mathrm{As}$ ) have a ratio value of $<1$ for all fuels due to their preferred concentration in deposits. The results confirmed the higher volatility of trace elements $\mathrm{Zn}, \mathrm{Pb}$ and As.
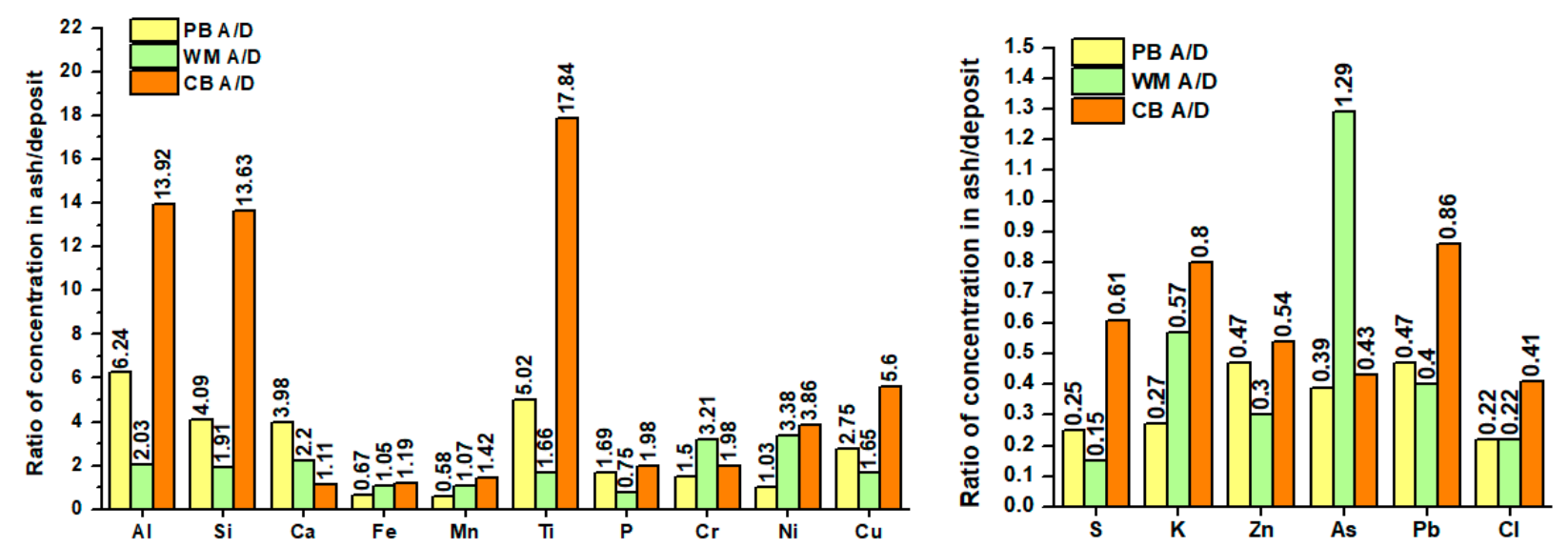

Figure 10. Ratios of concentrations of elements in ash/deposits (A/D) calculated from arithmetic mean values.

\subsection{The Influence of Principles of the Circular Economy for Residential Heating Fuels}

Primarily, the aim of the circular economy (CE) is to protect primary raw material resources, including wood. CE is a regenerative method in which raw material input, waste generation, emissions, and energy are minimized by promoting the circularity of material and energy achieved by repair, reuse, remanufacture, refurbishing, and recycling [84]. The use of wood residues for energy is a natural part of the circular economy of the forest and wood industry. The partial replacement of wood or wood by-products (sawdust, shavings) with wood-based waste paper and cardboard could make a significant contribution to saving primary raw materials, especially in areas where waste paper and cardboard cannot be reused for the paper industry. At the same time, this option reduces the proportion of waste dumped ineffectively in landfills.

With the addition of $50 \%$ cardboard to wood chips, the price of the fuel input drops by $50 \%$ [85]. A similar price drop in the use of cardboard for briquette production has not been confirmed in the Czech Republic, and in the production of mono-fuel from cardboard, the price is even higher than for wood briquettes or sawmill briquettes. The price of briquettes made from sawdust and kindling from the production of wood (WOOD briquettes) in the Czech Republic is EUR 2.20/10 kg, and the price of "MIXI" briquettes made with the addition of $20 \%$ pure cardboard paper is EUR $1.92 / 10 \mathrm{~kg}$. The price difference is only $13 \%$ [86]. NIGHT briquettes are only made from waste cardboard, are the most expensive (EUR 2.71/10 kg), and have the worst thermal parameters. WOOD briquettes have the lowest ash content of $<1.47 \%$ and the best higher heating value of $18.8 \mathrm{MJ} / \mathrm{kg}$, MIXI briquettes contain $<6.5 \%$ ash, and their higher heating value reaches $16.5 \mathrm{MJ} / \mathrm{kg}$, and NIGHT briquettes have the highest ash content of $13.04 \%$ and a higher heating value of $15 \mathrm{MJ} / \mathrm{kg}$. The use of "NIGHT" briquettes is specifically targeted at citizens who "want to be environmentally friendly". The prices of briquettes on the market in the Czech Republic are highly variable. Novak \& Novak Eko Co. (Česká Skalice, the Czech Republic) supplies 
briquette "beech cubes" at a price of EUR 1.62/10 kg, and briquettes from deciduous trees at EUR $1.42 / 10 \mathrm{~kg}$. Moreover, the price of briquettes changes significantly during the year. It is about $20 \%$ lower in the summer months. The price for $10 \mathrm{~kg}$ of EN-certified pellets plus A1 ranges from EUR 2.1-2.3/10 kg for one of the largest producers in the Czech Republic (BIOMAC Co.) and between EUR 1.8-2.0/10 kg for non-certified pellets [87]. The prices of pellets and briquettes are comparable. Their overproduction influences the price of both pellets and briquettes in the Czech Republic. In 2016, a total of 300,000 tonnes of pellets were produced, and 25,000 pellet boilers were put into operation. In 2020, forty factories in the Czech Republic produced 486,000 tonnes of pellets, and 40,000 pellet boilers were in operation. The greater part $(67 \%)$ of their annual production goes to exports. Almost all (96\%) of the pellets produced are EN plus A1-certified internationally [88]. Another important factor is the low price-the average price of wood pellets on the Ukrainian market is EUR 80-100, while the prices of this product in the European Union countries vary from EUR 180 to 220 for a tonne.

While there is an increasing pressure to use RES (Renewable Energy Sources) for residential combustion across Europe, the market price trends did not foresee any significant increase [89]. Prices fell between 2012 and 2016 from USD 208 to 190, and then rose slightly to USD 200 in 2018. A gradual increase in the cost of industrial wood pellets is expected to be likely, reaching above USD 250 per million tonnes by 2030 .

The market situation was influenced by the global COVID-19 pandemic for almost all commodities, such as lumber, where prices have increased by up to $200 \%$ over the past three months. Compared to the situation before the pandemic, COVID-19 lumber prices are up a staggering 188\% [90]. The price increase for lumber and wood products was also demonstrated by the Producer Price Index used in the USA, which rose to 400 (in 1982, the index value was set at 100), compared to 200 in 2015 [91].

However, many factors play a role in the choice of heating, and the price is one of several significant factors. Recently, the importance of circular economics principles has been increasing. The increasing demand for the use of chipboard panels for construction purposes will increase the pressure to recycle them, although this depends on the possibility of finding ways to detoxify them before recycling or utilization of natural resins as a replacement for synthetic resins [92]. These missing proportions of waste wood could be replaced by waste paper and cardboard. Currently, the technology and waste-reclaiming process that turns cellulose residue from cardboard into a fully recyclable construction material (Honext) are already available.

In terms of local approach, to ensure self-sufficiency in the biomass supply for residential combustion, and, based on experimental results on the amounts of elements emitted when burning paper briquettes, we recommend the production of briquettes with a maximum of $10 \%$ added cardboard. This will ensure compliance with the requirements for briquette quality according to "EN ISO 17225-3 Solid biofuels-Fuel specifications and classes-Part 3: Graded wood briquettes (3\% ash for briquettes group B)". It is also possible to combine it with the otherwise unused material with a minimal negative impact on the environment.

\section{Conclusions}

The basic parameter for assessing the environmental impact of domestic boilers is the amount of dust particles emitted. The amount of dust particles is related to the chemical nature of the particles (the presence of inorganic and organic components) and the form of the element presence and binding into the fuel matrix. A comparison between the combustion of fossil fuel (coal briquettes), biomass containing the minimum amount of waste wood (WM) which was prepared according to the requirements of the standard ISO 17225-7 [22], and briquettes from waste cardboard and paper shows that PB releases the highest amounts of major elements (up to $57 \mathrm{~g} / \mathrm{kg}$ of fuel) into the atmosphere, while the corresponding values are $22-28 \mathrm{~g} / \mathrm{kg}$ for WM and $22-23 \mathrm{~g} / \mathrm{kg}$ of fuel for CB. Similar results were obtained for trace elements ( $\mathrm{As}, \mathrm{Cu}, \mathrm{Cr}, \mathrm{Mn}, \mathrm{Ni}, \mathrm{Pb}$, and $\mathrm{Zn}$ ) and chlorine. 
Burning $1 \mathrm{~kg}$ of WM released $0.38-0.41 \mathrm{~g} / \mathrm{kg}$ into the atmosphere. In the case of $\mathrm{PB}$, it is $0.63-0.82 \mathrm{~g} / \mathrm{kg}$, and, in the case of $\mathrm{CB}, 0.20-0.21 \mathrm{~g} / \mathrm{kg}$. Major elements and quantities of unburned carbon decisively influence the overall production of emitted particles. A comparison of BEC2 and BEC 3 boilers shows that the modification of the combustion conditions (the amount of air added) is involved in the change in the phase composition of the particles in the deposits from CB. In the case of optimal oxidation conditions, the combustion of $C B$ produces hematite in addition to maghemite. When burning WM and $\mathrm{PB}$ in BEC2 and BEC3, differences in the amounts of elements released into the air were generally not significant. At the present time, the quality of combustion fuel has a significant impact in terms of reducing the amounts of elements released into the air. Any addition of waste materials (including wood) contributes to increasing the amounts of elements released into the atmosphere. It is very important to follow the rules of the circular economy, which emphasize further recovery of waste, but their further thermal recovery must respect information on the behaviour of elements during combustion processes.

Further research should include the verification of the possibility of producing "clean fuel" from cardboard by removing fillers and additives and an assessment of the economic and energy requirements of this production.

Author Contributions: Conceptualisation, H.R.; methodology, J.R. and D.J.; software, B.Š., P.K. and M.K.; validation, K.S., H.R. and D.J.; investigation, P.K., B.S.., J.R., M.K. and Š.F.; writing—original draft preparation, H.R., P.K., D.J. and J.R.; writing—review and editing, K.S.; visualisation, B.Š., Š.F. and M.K.; supervision, H.R. All authors have read and agreed to the published version of the manuscript.

Funding: This research was funded by Ministry of Education, Youth and Sport of the Czech Republic, CZ.02.1.01/0.0/0.0/18_069/0010049 "Research on the identification of combustion of unsuitable fuels and systems of self-diagnostics of boilers combusting solid fuels for domestic heating".

Institutional Review Board Statement: Not applicable.

Informed Consent Statement: Not applicable.

Data Availability Statement: Data available in a publicly accessible repository.

Acknowledgments: This work was supported by the project of the Ministry of Education, Youth and Sport of the Czech Republic-CZ.02.1.01/0.0/0.0/18_069/0010049 "Research on the identification of combustion of unsuitable fuels and systems of self-diagnostics of boilers combusting solid fuels for domestic heating".

Conflicts of Interest: The authors declare no conflict of interest. The funders had no role in the design of the study; in the collection, analyses, or interpretation of data; in the writing of the manuscript, or in the decision to publish the results.

\section{Abbreviations}

The following abbreviations are used in this manuscript:

$\begin{array}{ll}\text { A } & \text { Ash } \\ \text { BEC2 } & \text { Boilers of emission class EC2 } \\ \text { BEC3 } & \text { Boilers of emission class EC3 } \\ \text { CB } & \text { Coal briquettes } \\ \text { D } & \text { Deposits } \\ \text { EC } & \text { Elemental carbon } \\ \text { EC2,3 } & \text { Emission class 2,3 } \\ \text { EEA } & \text { European Environment Agency } \\ \text { EF } & \text { Emission factors } \\ \text { EMEP } & \text { European Monitoring and Evaluation Programme } \\ \text { F } & \text { Fuel } \\ \text { FC } & \text { Fuel consumption } \\ \text { MDF } & \text { Medium-density fibrewood } \\ \text { OC } & \text { Organic carbon }\end{array}$




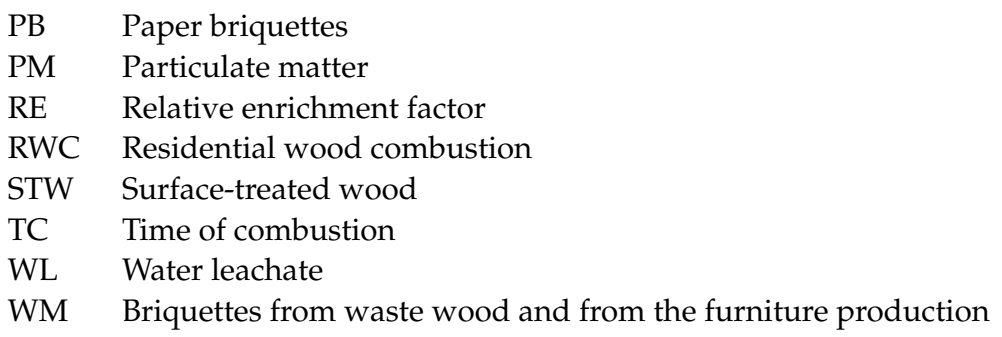

\section{References}

1. Nunes, L.J.R.; Matias, J.C.O.; Catalão, J.P.S. Biomass in the Generation of Electricity in Portugal: A Review. Renew. Sustain. Energy Rev. 2017, 71, 373-378. [CrossRef]

2. Savolahti, M.; Karvosenoja, N.; Kupiainen, K. Ecodesign Directive for Residential Wood Combustion Appliances: Impacts and Emission Reduction Potential in Finland. WIT Trans. Ecol. Environ. 2014, 191, 1493-1504. [CrossRef]

3. Malico, I.; Nepomuceno Pereira, R.; Gonçalves, A.C.; Sousa, A.M.O. Current Status and Future Perspectives for Energy Production from Solid Biomass in the European Industry. Renew. Sustain. Energy Rev. 2019, 112, 960-977. [CrossRef]

4. Sterman, J.D.; Siegel, L.; Rooney-Varga, J.N. Does Replacing Coal with Wood Lower $\mathrm{CO}_{2}$ Emissions? Dynamic Lifecycle Analysis of Wood Bioenergy. Environ. Res. Lett. 2018, 13, 015007. [CrossRef]

5. Millward-Hopkins, J.; Purnell, P. Circulating Blame in the Circular Economy: The Case of Wood-Waste Biofuels and Coal Ash. Energy Policy 2019, 129, 168-172. [CrossRef]

6. Kukkonen, J.; López-Aparicio, S.; Segersson, D.; Geels, C.; Kangas, L.; Kauhaniemi, M.; Maragkidou, A.; Jensen, A.; Assmuth, T.; Karppinen, A.; et al. The Influence of Residential Wood Combustion on the Concentrations of $\mathrm{PM}_{2.5}$ in Four Nordic Cities. Atmos. Chem. Phys. 2020, 20, 4333-4365. [CrossRef]

7. Trojanowski, R.; Fthenakis, V. Nanoparticle Emissions from Residential Wood Combustion: A Critical Literature Review, Characterisation, and Recommendations. Renew. Sustain. Energy Rev. 2019, 103, 515-528. [CrossRef]

8. Cincinelli, A.; Guerranti, C.; Martellini, T.; Scodellini, R. Residential Wood Combustion and Its Impact on Urban Air Quality in Europe. Curr. Opin. Environ. Sci. Health 2019, 8, 10-14. [CrossRef]

9. Shen, G.; Xue, M.; Chen, Y.; Yang, C.; Li, W.; Shen, H.; Huang, Y.; Zhang, Y.; Chen, H.; Zhu, Y.; et al. Comparison of Carbonaceous Particulate Matter Emission Factors among Different Solid Fuels Burned in Residential Stoves. Atmos. Environ. 2014, 89, 337-345. [CrossRef]

10. Kindbom, K.; Mawdsley, I.; Nielsen, O.-K.; Saarinen, K.; Jónsson, K.; Aasestad, K. Emission Factors for SLCP Emissions from Residential Wood Combustion in the Nordic Countries; TemaNord; 2017:570.; Nordic Council of Ministers: Copenhagen, Denmark, 2018; ISBN 978-92-893-5284-0.

11. Butcher, S.S.; Ellenbecker, M.J. Particulate Emission Factors for Small Wood and Coal Stoves. J. Air Pollut. Control. Assoc. 1982, 32, 380-384. [CrossRef]

12. Gonçalves, C.; Alves, C.; Evtyugina, M.; Mirante, F.; Pio, C.; Caseiro, A.; Schmidl, C.; Bauer, H.; Carvalho, F. Characterisation of PM10 Emissions from Woodstove Combustion of Common Woods Grown in Portugal. Atmos. Environ. 2010, 44, 4474-4480. [CrossRef]

13. Canha, N.; Lopes, I.; Vicente, E.D.; Vicente, A.M.; Bandowe, B.A.M.; Almeida, S.M.; Alves, C.A. Mutagenicity Assessment of Aerosols in Emissions from Domestic Combustion Processes. Environ. Sci. Pollut. Res. 2016, 23, 10799-10807. [CrossRef] [PubMed]

14. Seljeskog, M.; Sevault, A.; Østnor, A.; Skreiberg, Ø. Variables Affecting Emission Measurements from Domestic Wood Combustion. Energy Procedia 2017, 105, 596-603. [CrossRef]

15. European Environment Agency. EMEP/EEA Air Pollutant Emission Inventory Guidebook 2016: Technical Guidance to Prepare National Emission Inventories; European Environment Agency: Copenhagen, Denmark, 2016; ISBN 978-92-9213-806-6.

16. Klimont, Z.; Kupiainen, K.; Heyes, C.; Purohit, P.; Cofala, J.; Rafaj, P.; Borken-Kleefeld, J.; Schöpp, W. Global Anthropogenic Emissions of Particulate Matter Includingblack Carbon; Aerosols/Atmospheric Modelling/Troposphere/Chemistry (chemical composition and reactions). Atmos. Chem. Phys. Discuss. 2016, 17. [CrossRef]

17. Amaral, S.; de Carvalho, J.; Costa, M.; Pinheiro, C. Particulate Matter Emission Factors for Biomass Combustion. Atmosphere 2016, 7, 141. [CrossRef]

18. Deng, M.; Li, P.; Ma, R.; Shan, M.; Yang, X. Air Pollutant Emission Factors of Solid Fuel Stoves and Estimated Emission Amounts in Rural Beijing. Environ. Int. 2020, 138, 105608. [CrossRef] [PubMed]

19. van Lith, S.C.; Alonso-Ramírez, V.; Jensen, P.A.; Frandsen, F.J.; Glarborg, P. Release to the Gas Phase of Inorganic Elements during Wood Combustion. Part 1: Development and Evaluation of Quantification Methods. Energy Fuels 2006, 20, 964-978. [CrossRef]

20. Chen, C.; Luo, Z.; Yu, C. Release and Transformation Mechanisms of Trace Elements during Biomass Combustion. J. Hazard. Mater. 2019, 380, 120857. [CrossRef]

21. Paulauskas, R.; Striūgas, N.; Sadeckas, M.; Sommersacher, P.; Retschitzegger, S.; Kienzl, N. Online Determination of Potassium and Sodium Release Behaviour during Single Particle Biomass Combustion by FES and ICP-MS. Sci. Total Environ. 2020, 746, 141162. [CrossRef] 
22. ISO 17225-7:2014. Solid Biofuels-Fuel Specifications and Classes-Part 7: Graded Non-Woody Briquettes; ISO: Geneva, Switzerland, 2014.

23. Masiello, C.A. New Directions in Black Carbon Organic Geochemistry. Mar. Chem. 2004, 92, 201-213. [CrossRef]

24. Han, Y.M.; Cao, J.J.; Lee, S.C.; Ho, K.F.; An, Z.S. Different Characteristics of Char and Soot in the Atmosphere and Their Ratio as an Indicator for Source Identification in Xi'an, China. Atmos. Chem. Phys. 2010, 10, 595-607. [CrossRef]

25. European Committee for Standardization. EN 303-5: Heating Boilers-Part 5: Heating Boilers for Solid Fuels, Manually and Automatically Stoked, Nominal Heat Output of up to 500 KW-Terminology, Requirements, Testing and Marking; European Committee for Standardization: Brussels, Belgium, 2012.

26. Růžičková, J.; Kucbel, M.; Raclavská, H.; Švédová, B.; Raclavský, K.; Juchelková, D. Comparison of Organic Compounds in Char and Soot from the Combustion of Biomass in Boilers of Various Emission Classes. J. Environ. Manag. 2019, 236, 769-783. [CrossRef] [PubMed]

27. ISO. ISO 18122:2015 Solid Biofuels—Determination of Ash Content; ISO: Geneva, Switzerland, 2015.

28. ISO. ISO 16948:2015 Solid Biofuels—Determination of Total Content of Carbon, Hydrogen and Nitrogen; ISO: Geneva, Switzerland, 2015.

29. ISO. ISO 18125:2017 Solid Biofuels—Determination of Calorific Value; ISO: Geneva, Switzerland, 2017.

30. US EPA. US EPA Field Portable X-ray Fluorescence Spectrometry for the Determination of Elemental Concentrations in Soil and Sediment. (Method 6200); US EPA: Washington, DC, USA, 2007.

31. ISO. ISO 18134-2:2017 Solid Biofuels—Determination of Moisture Content_Oven Dry Method_Part 2: Total Moisture-Simplified Method; ISO: Geneva, Switzerland, 2017.

32. European Committee for Standardization. EN 12457-4:2002 Characterisation of Waste-Leaching-Compliance Test for Leaching of Granular Waste Materials and Sludges_-Part 4: One Stage Batch Test at a Liquid to Solid Ratio of $10 \mathrm{l} / \mathrm{Kg}$ for Materials with Particle Size below $10 \mathrm{Mm}$ (without or with Size Reduction); European Committee for Standardization: Brussels, Belgium, 2002.

33. US. EPA. Method 300.1: Determination of Inorganic Anions in Drinking Water by Ion Chromatography; US EPA: Washington, DC, 1997.

34. ASTM International. ASTM D293/D293M-18: Standard Test Method for the Sieve Analysis of Coke; ASTM International: West Conshohocken, PA, USA, 2018.

35. ISO. ISO 17827-2:2016 Solid Biofuels-Determination of Particle Size Distribution for Uncompressed Fuels-Part 2: Vibrating Screen Method Using Sieves with Aperture of $3.15 \mathrm{~mm}$ and Below; ISO: Geneva, Switzerland, 2016.

36. Kataki, R.; Chutia, R.S.; Mishra, M.; Bordoloi, N.; Saikia, R.; Bhaskar, T. Feedstock suitability for thermochemical processes. In Recent Advances in Thermo-Chemical Conversion of Biomass; Elsevier: Amsterdam, The Netherlands, 2015; pp. 31-74, ISBN 978-0-444-63289-0.

37. Elmas, G.M.; Çınar, G. Toxic Metals in Paper and Paperboard Food Packagings. BioResources 2018, 13, 7560-7580. [CrossRef]

38. Ginebreda, A.; Guillén, D.; Barceló, D.; Darbra, R.M. Additives in the paper industry. In Global Risk-Based Management of Chemical Additives I; Bilitewski, B., Darbra, R.M., Barceló, D., Eds.; The Handbook of Environmental Chemistry; Springer: Berlin/Heidelberg, Germany, 2011; Volume 18, pp. 11-34, ISBN 978-3-642-24875-7.

39. Kim, K.-C.; Park, Y.-B.; Lee, M.-J.; Kim, J.-B.; Huh, J.-W.; Kim, D.-H.; Lee, J.-B.; Kim, J.-C. Levels of Heavy Metals in Candy Packages and Candies Likely to Be Consumed by Small Children. Food Res. Int. 2008, 41, 411-418. [CrossRef]

40. Ishchenko, V.; Vasylkivskyi, I. Environmental Pollution with Heavy Metals: Case Study of the Household Waste. In Sustainable Production: Novel Trends in Energy, Environment and Material Systems; Królczyk, G.M., Wzorek, M., Król, A., Kochan, O., Su, J., Kacprzyk, J., Eds.; Studies in Systems, Decision and Control; Springer International Publishing: Cham, Switzerland, 2020; Volume 198, pp. 161-175, ISBN 978-3-030-11273-8.

41. Wang, X.; Song, A.; Li, L.; Li, X.; Zhang, R.; Bao, J. Effect of Calcium Carbonate in Waste Office Paper on Enzymatic Hydrolysis Efficiency and Enhancement Procedures. Korean J. Chem. Eng. 2011, 28, 550-556. [CrossRef]

42. Mertoglu-Elmas, G. The Effect of Colorants on the Content of Heavy Metals in Recycled Corrugated Board Papers. BioResources 2017, 12, 2690-2698. [CrossRef]

43. Vassilev, S.V.; Vassileva, C.G.; Song, Y.-C.; Li, W.-Y.; Feng, J. Ash Contents and Ash-Forming Elements of Biomass and Their Significance for Solid Biofuel Combustion. Fuel 2017, 208, 377-409. [CrossRef]

44. Yan, J.; Karlsson, A.; Zou, Z.; Dai, D.; Edlund, U. Contamination of Heavy Metals and Metalloids in Biomass and Waste Fuels: Comparative Characterisation and Trend Estimation. Sci. Total Environ. 2020, 700, 134382. [CrossRef] [PubMed]

45. European Parliament. European Council of the European Union Directive (EU) 2018/852 of the European Parliament and of the Council of 30 May 2018 Amending Directive 94/62/EC on Packaging and Packaging Waste (Text with EEA Relevance); European Parliament: Brussels, Belgium, 2018.

46. Vassilev, S.V.; Baxter, D.; Andersen, L.K.; Vassileva, C.G. An Overview of the Composition and Application of Biomass Ash. Part 1. Phase-Mineral and Chemical Composition and Classification. Fuel 2013, 105, 40-76. [CrossRef]

47. Vassilev, S.V.; Baxter, D.; Andersen, L.K.; Vassileva, C.G.; Morgan, T.J. An Overview of the Organic and Inorganic Phase Composition of Biomass. Fuel 2012, 94, 1-33. [CrossRef]

48. Piotrowska, P.; Zevenhoven, M.; Hupa, M.; Davidsson, K.; Åmand, L.E.; Zabetta, E.C.; Barišić, V. Fate of Phosphorus during Co-Combustion of Rapeseed Cake with Wood. In Proceedings of the 20th International Conference on Fluidized Bed Combustion, Xi'an, China, 18 May 2009; pp. 979-986.

49. Krook, J.; Mårtensson, A.; Eklund, M. Sources of Heavy Metal Contamination in Swedish Wood Waste Used for Combustion. Waste Manag. 2006, 26, 158-166. [CrossRef] [PubMed] 
50. Kakitani, T.; Hata, T.; Kajimoto, T.; Imamura, Y. A Novel Extractant for Removal of Hazardous Metals from Preservative-treated Wood Waste. J. Environ. Qual. 2006, 35, 912-917. [CrossRef]

51. Kim, J.-Y.; Oh, S.; Park, Y.-K. Overview of Biochar Production from Preservative-Treated Wood with Detailed Analysis of Biochar Characteristics, Heavy Metals Behaviors, and Their Ecotoxicity. J. Hazard. Mater. 2020, 384, 121356. [CrossRef]

52. Werkelin, J.; Lindberg, D.; Boström, D.; Skrifvars, B.-J.; Hupa, M. Ash-Forming Elements in Four Scandinavian Wood Species Part 3: Combustion of Five Spruce Samples. Biomass Bioenergy 2011, 35, 725-733. [CrossRef]

53. Jones, F.; Bankiewicz, D.; Hupa, M. Occurrence and Sources of Zinc in Fuels. Fuel 2014, 117, 763-775. [CrossRef]

54. Kuchler, C.; Kuptz, D.; Rist, E.; Mack, R.; Schön, C.; Zimmermann, D.; Dietz, E.; Riebler, M.; Blum, U.; Borchert, H.; et al. Contamination of Wood Pellets with Selected Mineral Soils-Fuel Quality and Combustion Behaviour. In Proceedings of the 27th European Biomass Conference and Exhibition, Lisbon, Portugal, 27 May 2019; pp. 673-680.

55. Finkelman, R.B. Trace and Minor Elements in Coal. In Organic Geochemistry; Engel, M.H., Macko, S.A., Eds.; Topics in Geobiology; Springer US: Boston, MA, USA, 1993; Volume 11, pp. 593-607, ISBN 978-1-4613-6252-4.

56. Finkelman, R.B.; Palmer, C.A.; Wang, P. Quantification of the Modes of Occurrence of 42 Elements in Coal. Int. J. Coal Geol. 2018, 185, 138-160. [CrossRef]

57. Gluskoter, H.J. Mineral Matter and Trace Elements in Coal. In Trace Elements in Fuel: A Symposium Sponsored by the Division of Fuel Chemistry, Proceedings of the 166th Meeting of the American Chemical Society, Chicago, IL, USA, 30 August 1973; Babu, S.P., American Chemical Society, Eds.; Advances in Chemistry Series; American Chemical Society: Washington, DC, USA, 1975; pp. 1-22, ISBN 978-0-8412-0216-0.

58. Lewińska-Preis, L.; Fabiańska, M.J.; Ćmiel, S.R.; Kita, A. Geochemical Distribution of Trace Elements in Kaffioyra and Longyearbyen Coals, Spitsbergen, Norway. Int. J. Coal Geol. 2009, 80, 213-223. [CrossRef]

59. Ketris, M.P.; Yudovich, Y.E. Estimations of Clarkes for Carbonaceous Biolithes: World Averages for Trace Element Contents in Black Shales and Coals. Int. J. Coal Geol. 2009, 78, 135-148. [CrossRef]

60. Tomza, U.; Kaleta, P. Trace Elements in Brown Coal and Its Products of Combustion. J. Radioanal. Nucl. Chem. Lett. 1986, 107, 1-10. [CrossRef]

61. Xu, M.; Yan, R.; Zheng, C.; Qiao, Y.; Han, J.; Sheng, C. Status of Trace Element Emission in a Coal Combustion Process: A Review. Fuel Process. Technol. 2004, 85, 215-237. [CrossRef]

62. Vöröš, D.; Geršlová, E.; Díaz-Somoano, M.; Sýkorová, I.; Suárez-Ruiz, I.; Havelcová, M.; Kuta, J. Distribution and Mobility Potential of Trace Elements in the Main Seam of the Most Coal Basin. Int. J. Coal Geol. 2018, 196, 139-147. [CrossRef]

63. Jensen, P.A.; Jappe Frandsen, F.; Wu, H.; Glarborg, P. A Review: Fly Ash and Deposit Formation in PF Fired Biomass Boilers. In Proceedings of the Impacts of Fuel Quality on Power Production, Prague, Czech Republic, 19 September 2016.

64. Sommersacher, P.; Brunner, T.; Obernberger, I. Fuel Indexes: A Novel Method for the Evaluation of Relevant Combustion Properties of New Biomass Fuels. Energy Fuels 2012, 26, 380-390. [CrossRef]

65. Truex, T.J.; Hammerle, R.H.; Armstrong, R.A. The Thermal Decomposition of Aluminium Sulfate. Thermochim. Acta 1977, 19, 301-304. [CrossRef]

66. Fromm, J. Wood Formation of Trees in Relation to Potassium and Calcium Nutrition. Tree Physiol. 2010, 30, 1140-1147. [CrossRef] [PubMed]

67. Rajamma, R.; Ball, R.J.; Tarelho, L.A.C.; Allen, G.C.; Labrincha, J.A.; Ferreira, V.M. Characterisation and Use of Biomass Fly Ash in Cement-Based Materials. J. Hazard. Mater. 2009, 172, 1049-1060. [CrossRef] [PubMed]

68. Frost, R.L.; Weier, M.L.; Martens, W.; Theo Kloprogge, J.; Ding, Z. Thermal Decomposition of the Vivianite Arsenates-Implications for Soil Remediation. Thermochim. Acta 2003, 403, 237-249. [CrossRef]

69. Cohen, Y.; Aizenshtat, Z. Investigation of Pyrolytically Produced Condensates of Phenol-Formaldehyde Resins, in Relation to Their Structure and Decomposition Mechanism. J. Anal. Appl. Pyrolysis 1992, 22, 153-178. [CrossRef]

70. Wang, Z.D.; Yoshida, M.; George, B. Theoretical Study on the Thermal Decomposition of Thiourea. Comput. Theor. Chem. 2013, 1017, 91-98. [CrossRef]

71. Yu, D.; Zhao, L.; Zhang, Z.; Wen, C.; Xu, M.; Yao, H. Iron Transformation and Ash Fusibility during Coal Combustion in Air and $\mathrm{O}_{2} / \mathrm{CO}_{2}$ Medium. Energy Fuels 2012, 26, 3150-3155. [CrossRef]

72. Vandenberghe, R.E.; de Resende, V.G.; da Costa, G.M.; De Grave, E. Study of Loss-on-Ignition Anomalies Found in Ashes from Combustion of Iron-Rich Coal. Fuel 2010, 89, 2405-2410. [CrossRef]

73. Yang, T.; Liu, Q.; Chan, L.; Cao, G. Magnetic Investigation of Heavy Metals Contamination in Urban Topsoils around the East Lake, Wuhan, China. Geophys. J. Int. 2007, 171, 603-612. [CrossRef]

74. Wang, B.; Wang, S.-F.; Lam, S.S.; Sonne, C.; Yuan, T.-Q.; Song, G.-Y.; Sun, R.-C. A Review on Production of Lignin-Based FLocculants: Sustainable Feedstock and Low Carbon Footprint Applications. Renew. Sustain. Energy Rev. 2020, $134,110384$. [CrossRef]

75. Bertella, S.; Luterbacher, J.S. Lignin Functionalisation for the Production of Novel Materials. Trends Chem. 2020, 2, 440-453. [CrossRef]

76. Jakab, E.; Faix, O.; Till, F.; Székely, T. The Effect of Cations on the Thermal Decomposition of Lignins. J. Anal. Appl. Pyrolysis 1993, 25, 185-194. [CrossRef] 
77. Liu, L.; Kong, S.; Zhang, Y.; Wang, Y.; Xu, L.; Yan, Q.; Lingaswamy, A.P.; Shi, Z.; Lv, S.; Niu, H.; et al. Morphology, Composition, and Mixing State of Primary Particles from Combustion Sources-Crop Residue, Wood, and Solid Waste. Sci. Rep. 2017, 7, 5047. [CrossRef]

78. Ibrahim, H.G.; Ouiminga, S.K.; Yonli, A.; Sanogo, O.; Daho, T.; Koulidiati, J. Study of Temperature Fields and Heavy Metal Content in the Ash and Flue Gas Produced by the Combustion of Briquettes Coming from Paper and Cardboard Waste. Recycling 2018, 3, 32. [CrossRef]

79. Yu, J.; Sun, L.; Wang, B.; Qiao, Y.; Xiang, J.; Hu, S.; Yao, H. Study on the Behavior of Heavy Metals during Thermal Treatment of Municipal Solid Waste (MSW) Components. Environ. Sci. Pollut. Res. 2016, 23, 253-265. [CrossRef]

80. Beck, J.; Unterberger, S. The Behaviour of Particle Bound Phosphorus during the Combustion of Phosphate Doped Coal. Fuel 2007, 86, 632-640. [CrossRef]

81. Raclavska, H.; Juchelkova, D.; Roubicek, V.; Matysek, D. Energy Utilisation of Biowaste-Sunflower-Seed Hulls for Co-Firing with Coal. Fuel Process. Technol. 2011, 92, 13-20. [CrossRef]

82. Mokhtar, M.M.; Taib, R.M.; Hassim, M.H. Understanding Selected Trace Elements Behavior in a Coal-Fired Power Plant in Malaysia for Assessment of Abatement Technologies. J. Air Waste Manag. Assoc. 2014, 64, 867-878. [CrossRef]

83. Meij, R. The Distribution of Trace Elements During the Combustion of Coal. In Environmental Aspects of Trace Elements in Coal; Swaine, D.J., Goodarzi, F., Eds.; Energy \& Environment; Springer: Dordrecht, The Netherlands, 1995; Volume 2, pp. 111-127. ISBN 978-90-481-4606-2.

84. Geissdoerfer, M.; Savaget, P.; Bocken, N.M.P.; Jan, E. The Circular Economy-A new sustainability paradigm? J. Clean. Prod. 2017, 143, 757-768. [CrossRef]

85. Lela, B.; Barišić, M.; Nižetić, S. Cardboard/sawdust Briquettes as Biomass Fuel: Physical-mechanical and Thermal Characteristics. Waste Manag. 2016, 47, 236-245. [CrossRef]

86. Besta Building Materials: Chopped Wood, Briquettes, Pellets. Available online: https://www.stavebniny-besta.cz/palivo/ (accessed on 22 May 2021). (In Czech)

87. Biomac: Wood Briquettes, Wood Pellets. Available online: https:/ / eshop.biomac.cz/ (accessed on 23 May 2021). (In Czech)

88. About Homemade Pellets. Available online: https://www.koupitpelety.cz/domaci-pelety (accessed on 22 May 2021). (In Czech)

89. Strauss, W. Forecasting Industrial Wood Pellet Prices. Biomass Magazine. Available online: http://biomassmagazine.com/ articles/15610/forecasting-industrial-wood-pellet-prices (accessed on 24 September 2018).

90. Lambert, L. Lumber Prices Are up a Staggering 188\%—When Will the Wood Shortage End? Available online: https: / / fortune.com/2021/03/20/lumber-prices-2021-chart-when-will-wood-shortage-end-price-of-lumber-go-down-home-salescost-update-march (accessed on 20 March 2021).

91. U.S. Bureau of Labor Statistics, Producer Price Index by Commodity: Lumber and Wood Products: Softwood Lumber [WPU0811]. FRED, Federal Reserve Bank of St. Louis. Available online: https:/ / fred.stlouisfed.org/series/WPU0811 (accessed on 13 March 2021).

92. de Carvalho Araújo, C.K.; Salvador, R.; Piekarski, C.M.; Sokulski, C.C.; de Francisco, A.C.; de Carvalho Araújo Camargo, S.K. Circular Economy Practices on Wood Panels: A Bibliographic Analysis. Sustainability 2019, 11, 1057. [CrossRef] 